\title{
MÜSABAKA ALANLARINDAKİ SPORCULARIN HAKARET İÇEREN EYLEMLERİ İLE KASTEN YARALAMA VE MALA ZARAR VERME EYLEMLERININ TÜRK CEZA HUKUKU AÇISINDAN DEĞERLENDİRILMESİ
}

DOI: https://doi.org/10.33717/deuhfd.642008

\section{Dr. Rezan EPÖZDEMIR*}

\section{$\ddot{\mathbf{O z}}$}

Sanayileşmenin etkisi ile birlikte kapsamı genişleyen ve ekonomik bir faaliyet olarak kabul edilen spor ve bilhassa seyir yönü yüksek olan futbol günümüzde milyonlarca insanı peşinden sürükleyen bir sektör haline dönüşmüştür. Futbolun böyle bir kimliğe bürünmüş olması her açıdan olumlu karşılansa da sektörün en büyük handikapı olan şiddet ve düzensizlik vakıalarını unutmamak gerekir. Başta futbol müsabakaları olmak üzere, tüm spor müsabakalarında son zamanlarda artan şiddet ve düzensizliklerin önüne geçilmesi için kanun koyucu tarafindan öncelikle 5149 sayll Spor Müsabakalarında Şiddet ve Düzensizliğin Önlenmesine Dair Kanun kaleme alınmış, akabinde işbu kanunun ihtiyaçlara cevap vermemesi sebebi ile 6222 sayll Sporda Şiddet ve Düzensizliğin Önlenmesine Dair Kanun ihdas edilmiştir. Bu kanunun 'yasak fiiller ve ceza hükümleri' başlıklı üçüncü bölümünde yasak fiiller ve bu fiillerin karşıllğında uygulanacak olan yaptırımlar düzenlenmiştir. Çalışmamızda bu yasak fiillerden kanunun 14. maddesinde hüküm altına alınan 'hakaret içeren tezahürat've yine kanunun 17. maddesinde hüküm altına alınan 'spor alanlarında taşkınlık yapılması ve tesislere zarar verilmesi' fiilleri Türk Ceza Hukuku açısından değerlendirilecek, konu ile ilgili doktrindeki tartışmalara ve ihtilaflı hususlara yer verilecek ve konu sporda şiddet ve düzensizliğin önlenmesi baklmından üzerine büyük bir sorumluluk düşen Yargıtay'ın kararları ile daha da detaylandırılacaktır.

\section{Anahtar Kelimeler}

Spor, Şiddet ve Düzensizlik, Hakaret, Kasten Yaralama, Mala Zarar Verme

İstanbul Barosu Avukatlarından (e-posta: analizhukuk@gmail.com) ORCID: https://orcid.org/0000-0003-4038-9447 (Makalenin Geliş Tarihi: 01.03.2019) (Makale Gönderilme Tarihi: 04.03.2019/Makale Kabul Tarihi: 11.06.2019) 


\title{
THE OFFENCES OF DEFAMATION, FELONIOUS INJURY AND DAMAGE TO PROPERTY OF ATHLETES IN TERMS OF TURKISH CRIMINAL LAW IN COMPETITION AREAS
}

\begin{abstract}
With the influence of industrialization, the scope of sports, which is considered as an economic activity and whose scope is expanding, has become a sector which has driven millions of people today. It is important to note that the fact that football has become such an identity is positively welcomed in every respect and the biggest handicap of the sector is violence and disorder. Law No. 5149 on Prevention of Violence and Disorder was first drafted by the legislator in order to prevent the increasing violence and irregularities in all sports competitions, particularly in football competitions. A Law was introduced. In the third section titled iller prohibited acts and penal provisions kars, the prohibited acts and the sanctions to be applied in return for these acts are regulated. In this study, the değerlendiril insulting cheering ilgili which is stipulated in Article 14 of the law and the inda flood in sports areas and damage to the facilities $l$, which are stipulated in Article 14 of the law, will be evaluated in terms of turkish criminal law, and the content of the disputes in the will be given and a major responsibility for the prevention of violence and irregularity in the sport in the matter will be further elaborated by the decisions of the Supreme Court.
\end{abstract}

\section{Keywords}

Sport, Violence and Disorder, Insult, Intentionally Injury, Damage to property 


\section{GENEL OLARAK SPOR VE SPOR HUKUKU}

Önceleri insanların yaşamlarını idame ettirebilmek amacıyla gerçekleştirdikleri, zamanın koşullarına göre günlük hayatın bir parçası olan zıplama, atlama, koşma gibi faaliyetler şeklinde karşımıza çıkan ve milattan önce 900'lü yılların başında 'kurallı bir yarışma' olarak adlandırılan spor, sanayileşmenin de etkisi ile birlikte daha çok insanların boş zamanlarını değerlendirmek, eğlenmek, vücut ve zihin sağlığını korumak ve geliştirmek için kullandıkları bir araç haline dönüşmüşs ${ }^{2}$ ve bu amaçlar uğrunda yapılan her türlü vücut ve zihin etkinliği olarak tanımlanmaya başlanmıştır. Türk Dil Kurumu ise sporu "bedeni veya zihni geliştirmek amacıyla kişisel veya toplu olarak gerçekleştirilen, bazı kurallara göre uygulanan hareketlerin tümü” olarak tanımlamıştır ${ }^{3}$. Ancak günümüzde sporun kapsamı bu tanımın içine sığmayacak kadar genişlemiş durumdadır. Günümüzde spor artık yalnızca eğlence veya sağlık nedeni ile değil, çoğunlukla ekonomik nedenlerle icra edilmektedir. Zira son yıllarda hem spor yapan hem de spor karşılaşmalarını izleyen kişilerin sayısındaki artış, spora yapılan yatırımların da çoğalmasını sağlamış; sponsorluk, reklam ve karşılaşmaların yayınlanması sayesinde para aktarımı hız kazanmıştır. Diğer taraftan sporun uluslararası niteliği ile birlikte medya gün geçtikçe spora daha çok eğilmiş, spordan elde edilen kazançların artmasına sebep olmuş ${ }^{4}$ ve profesyonellikle birlikte işe dönüşen spor adeta bir meslek halini almıştır ${ }^{5}$. Hal böyleyken günümüzde sporu ve

Fişek, Kurthan: Devlet Politikası ve Toplumsal Yapıyla İlişsileri Açısından Dünya'da ve Türkiye'de Spor Yönetimi, A.Ü SBF Yayınları, 2. Bası, Ankara 1998, s. 95.

6222 sayılı Sporda Şiddet ve Düzensizliğin Önlenmesine Dair Kanunun Genel Gerekçesi:

21 'inci yüzyılda uluslararasındaki aşılması zor sınırlar ortadan kalkmış, ulaşım ve teknoloji başta olmak üzere diğer alanlardaki gelişme ve bütünleşmelerle birlikte hem ulusal alanda hem de uluslararası alanda insanlar sosyal yaşamlarında spora daha çok zaman ayırmaya başlamışlardır. http://www.tdk.gov.tr, Erişim Tarihi: 21 Aralık 2019

4 Koçak, Talat Emre: Türkiye Futbol Federasyonu Tahkim Kurulu, Seçkin Yayıncılık, 1. Bask1, Ankara 2007, s. 15-16.

5 Baştürk, Faruk: İş Hukukunda Profesyonel Futbolcu, Beta Basım Yayın, 1. Bask1, İstanbul 2007, s. 2; Yine doktrinde başkaca yazarlar tarafından başlangıçta bir oyun ve işten uzaklaşma aracı olarak ortaya çıkan sporun, zamanla gerek ekonomik ve siyasal, gerekse uluslararası barış ve hukuki bakımlardan çok farklı bir görünüme kavuştuğu belirtilmiş; bu anlamda sporun çok yönlü etkileri olan bir toplumsal kurum haline büründüğü ve günlük hayatın vazgeçilmez bir parçası olduğu ifade edilmiştir. (Günal, A. Nadi/Küçükgüngör, Erkan: "Türk Spor Teşkilatının Hukuki Yapısı", Türkiye Barolar Birliği Dergisi, 1998/3, s. 1040; Saribrahimoğlu, Y. Selim/Bakanay, Mehmet Ali/ Tekin, Tarı: Spor Hukuku, Ankara 2002, s. 8) 
bilhassa seyir (estetik) yönü ${ }^{6}$ yüksek olan futbolu, ekonomik bir faaliyet olarak kabul etmek hiç de yanlış olmayacaktır. Nitekim ekonominin futbola etkisi 'futbolda topu döndüren paradır' (money makes the ball go round) şeklinde ifade edilmiştir ve bu bakımdan futbol, ekonomik bir fenomen olarak görülmüştür ${ }^{7}$.

Yukarıda ifade edildiği üzere bilhassa seyir (estetik) yönü yüksek olan futbol diğer spor dallarından ayrı bir gelişim göstermiş ${ }^{8}$ ve günümüzde milyonlarca insanı peşinden sürükleyen bir sektör haline dönüşmüştür9 ${ }^{9}$. Futbolun böyle bir kimliğe bürünmüş olması ekonomik, sosyal, toplumsal ve politik yönden olumlu karşılansa da, sektörün en büyük handikapı olan şiddet ve düzensizlik vakıalarını da unutmamak ve bu vakıaları bu kimliğin bir götürüsü olarak kabul etmek gerekir. Zira başta futbol sahaları olmak üzere spor alanlarında yaşanan holiganizm, rrkçılık içeren söylemler, organize suçlar, şike ve teşvik primi, hakem, sporcu ve diğer ilgililere karşı eylemli ve sözlü saldırılar gibi fiiller uluslararası alanda sporun temel sorunu olarak kabul edilmekte ve böylece spor alanlarında ortaya çıkan düzensizlik ve şiddet olaylarının önlenmesi basit bir asayiş sorununun ötesinde olağanüstü dikkat ve tedbir gerektiren bir durum olarak ele alınmaktadır. Bunun sonucu olarak da işbu alanın özel olarak değerlendirilmesi ve spor mevzuatının etkin bir şekilde düzenlenmesi gerekliliği ortaya çıkmaktadır. Her ne kadar doktrinde bazı yazarlar ${ }^{10}$ ve Yargitay $^{11}$ tarafindan spor hukukunun ayrı ve

6 Doktrinde Ertaş\&Petek sporun ekonomik, estetik ve politik yönlerinin varlığından bahsetmektedirler. Yazarlara göre "Sporun sadece eğlence ve sağlı nedeniyle değil, başka amaçlarla da yapılmaya başlanması, çağımızda sporun ikinci bir fonksiyonuna daha ağırlık kazandırmıştır; buna 'sporun estetik (gösteri) ve ekonomik fonksiyonu' denilmektedir... Sporun üçüncü bir boyutu ise, politik boyutudur. Sadece kulüpler veya ticaret şirketleri değil, devletler de sahip oldukları sporcuların gücüyle kendi güçlerini ispat ve başkalarını etkileme yoluna gitmektedirler.” (Ertaş, Şeref/Petek, Hasan: Spor Hukuku, Yetkin Yayınevi, 3. Bask1, Ankara 2017, s. 25-35)

7 Petek, Hasan: Profesyonel Futbolcu Sözleşmesi, Yetkin Yayınevi, 1. Baskı, Ankara 2002, s. 19; Güneș, İsmail: Futbol Ekonomisi, Karahan Kitabevi, 1. Bask1, Adana 2010, s. 230 vd.; Genç, Durmuş Ali: Futbol Kulüplerinin Stratejik Yönetimi, Bağırgan Yayınevi, Ankara 1999, s. 42.

8 "Bu gelişmede hiç şüphesiz ki, astronomik transfer ücretlerinin de payı bulunmaktadır." (Uzun, Aziz/Eker, Semih/ Pakiş, Iş1//Polat, Oğuz: "Üniversite Öğrencileri Arasında Sporda Şiddetin Önlenmesine Yönelik Farkındalık ve Bilgi Düzeyi Araştırması", Türkiye Biyoetik Derneği Yayınları, No: XVIII, İstanbul 2012, s. 304)

9 Karakaş Doğan, Fatma: "Futbol Taraftarlarının Hakaret Iç̧eren Tezahürat Eylemlerinin Ceza Hukuku Açısından Değerlendirilmesi”, Ceza Hukuku Dergisi, Cilt: 10, Sayı: 28, Ağustos 2015, Sayfa: 83-106.

10 Ertaş/Petek, s. 35. 
bağımsız bir hukuk dalı olarak kabul edilemeyeceği belirtilmişse de, kanaatimizce bu görüş yerinde değildir. Spor hukuku, gün geçtikçe diğer hukuk branşlarından bağımsızlaşmakta ve kendine özgü düzenlemelerle birlikte karma $^{12}$ niteliğe sahip bir hukuk dalı olarak karşımıza çıkmaktadır ${ }^{13}$. Nitekim başta 6222 sayılı Sporda Şiddet ve Düzensizliğin Önlenmesine Dair Kanun olmak üzere, gerek ulusal nitelikteki '5894 sayıl1 Türkiye Futbol Federasyonu Kuruluş ve Görevleri Hakkında Kanun', '3289 sayılı Gençlik ve Spor Genel Müdürlügünün Teşkilat ve Görevleri Hakkında Kanun’ ve '5253 sayılı Dernekler Kanunu', gerekse uluslararası nitelikteki 'Sportif Karşılaşmalarda ve Özellikle Futbol Maçlarında Seyircilerin Şiddet Gösterilerine ve Taşkınlıklarına Dair Avrupa Sözleşmesi', 'Sportif Karşılaşmalarda ve Özellikle Futbol Maçlarında Seyircilerin Şiddet Gösterilerine ve Taşkınlıklarına Dair Avrupa Sözleşmesi'ne göre kurulmuş Avrupa Konseyi tarafindan kabul edilen Tavsiye Kararları' ile 'Stadyumlarda Güvenliğin Sağlanmas1 ve Kitle Hareketlerinden Korunmak Amacı ile UEFA Kupalarında Oynanan Tüm Müsabakalara Katılan Kulüpler, Federasyonlar ve Maç Düzenleyicilerinin Tabi Olduğu Stadyum Güvenlik ve Emniyet Tedbirlerine

11 "Spor hukukunun ayrı ve bağımsız bir hukuk dalı olmadığının gözetilmesi gerekir." (Yargitay 4. Hukuk Dairesi, 28.06.2012, 2011/4716 Esas, 2012/11359 Karar, www.kazanci.com)

12 "Spor örgütleri, bazı ülkelerde dernek, bazılarında ise ticaret şirketleri veya her ikisinin karışımı şeklinde oluştuğu ve sporcu ile bu örgütler arasındaki ilişki dernek üyeliği şeklinde veya bir tür hizmet sözleşmesi olarak ortaya çıktığı için spor hukukunun bir medeni hukuk ya da ticaret hukuku dalı olduğu söylenebilir. Buna karşılık spor hukuku sporla ilgili bazı düzenlemelerin anayasalarda bulunması sebebiyle anayasa hukuku, spor kurallarının ihlalinin, ceza hukuku kurallarının uygulanmasını zorunlu kılması, özellikle sporculara ve spor örgütlerine verilen disiplin cezaları sebebiyle ceza hukuku, bir kamu hizmeti olarak sporun devletçe örgütlenmesi, bu hususta devletçe yaratılan imkanlar, kişilerin yararlanma koşullarının devletçe belirlenmesi sebebiyle ise idare hukuku niteliği dolayısıyla kamu hukuku niteliği taşımaktadır... Bütün bu açıklamalara göre spor hukukunu, özel hukuk ya da kamu hukuku veya milli hukuk ya da milletlerarası hukuk türlerinden sadece birisi içine yerleştirmek mümkün gözükmediği için, tüm bu dallara özgü niteliklerin görüldüğü 'karma bir hukuk dalı' olarak nitelendirmek isabetli olacaktır.” (Ertaş/Petek, s. 30); Doktrinde çoğunluk görüş, spor hukukunu karma bir hukuk kategorisi olarak görmektedir. Biz de çoğunluğun bu yöndeki görüşüne katılıyoruz. (Erten, Rifat: Milletlerarası Özel Hukukta Spor, Adalet Yayınevi, 1. Baskı, Ankara 2007, s. 55; Kocasakal, Ümit: "Spor Hukukunun Özellikleri Çerçevesinde Tahkim Yargllaması ve Türkiye Futbol Federasyonu Tahkim Kurulu”, İstanbul Barosu Dergisi Spor Hukuku Özel Sayısı, Mayıs 2007, s. 42; Özelçi, Aytaç: Türkiye Futbol Federasyonu'nun Türk Hukukundaki Yeri, Seçkin Yayıncılık, 1. Baskı, Ankara 2010, s. 24)

13 Erten, s. 53; Erkiner, Kısmet: “Türkiye'de Spor Hukukunun Oluşumu”, İstanbul Barosu Dergisi Spor Hukuku Özel Sayıs1, Mayıs 2007, s. 18. 
İlişkin Talimat' gibi normatif düzenlemelerin varlığı da, spor hukukunun ayrıca ele alınması gereken spesifik bir branş haline geldiğini gözler önüne sermektedir.

\section{6222 SAYILI KANUN KAPSAMINDA ÇALIŞMANIN KONUSUNA GENEL BİR BAKIŞ}

Cebir ve şiddet olaylarının az veya çok ortaya çıktığı boks, güreş, rugby, Uzakdoğu sporları gibi spor branşlar1 ${ }^{14}$ arasında kitle psikolojisinin yol açtığı şiddet olaylarının en sık rastlandığı spor branşı hiç şüphesiz ki futboldur ${ }^{15}$. Ne yazık ki, şiddet ile futbolun birlikteliği diğer alanlara göre daha az yadırganmakta ${ }^{16}$ ve futbolun rekabet ortam1 olan futbol sahalar1 ilgililerce, şiddetin meşrulaştırılmış bir alanı olarak görülmektedir ${ }^{17}$. Hal böyleyken başta futbol müsabakaları olmak üzere, tüm spor müsabakalarında son zamanlarda $\operatorname{artan}^{18}$ şiddet ve düzensizliklerin önüne geçilmesinin zaruri olduğu ve bu noktada kanun koyucuya da bir görev düştüğü tartışmasızdır. İşte kanun koyucu da kendisine düşen bu görevin bir yansıması olarak öncelikle 07/05/2004 tarihinde yürürlüğe giren, 5340 ve 5758 sayılı kanunlar ile iki kez değişikliğe uğratılan 5149 sayılı Spor Müsabakalarında Şiddet ve Düzensizliğin Önlenmesine Dair Kanun'u kaleme almış fakat işbu kanun 'taraftarların sürekli veya geçici olarak gruplar halinde bulundukları yer ve mekanlar ile müsabakanın yapılacağı yere gidiş ve geliş güzergahlarını kapsamaması, şike ve teşvik primi fiillerinin suç olarak tanımlanmaması, bazı yasak fiillerin karşılığında yaptırım öngörülmemesi, yaptırım öngörülenlerde ise idari para cezasına yer verilmiş olması, seyirden men tedbirine ilişkin hükmün Anayasa Mahkemesi tarafindan iptal edilmesi ve bu tedbirin uygulanabilirliğinin ortadan kalkması' gibi sebeplerle ihtiyaçlara cevap vereme-

14 Şen, Ersan: “6222 Sayılı Kanun ve Sporda Ceza Sorumluluğu”, http://www.haber7.com/yazarlar/prof-dr-ersan-sen/1692923-6222-sayili-kanun-vesporda-ceza-sorumlulugu, Erişim Tarihi: 4 Ocak 2019

Türkmen, Mustafa/Yıldız, Kadir/Zekioğlu, Aylin: "Sosyolojik Açıdan Şiddet ve Çirkin Tezahüratın Nedenlerinin Araştırılmast: Manisaspor Taraftarları Örneği”, Spor Yönetimi ve Bilgi Teknolojileri Dergisi, C: 8, S: 2, 2013, s. 17-18.

16 Kuru, Emin: Türkiye'de Spor Seyircilerinde Oluşan Kitlesel Tezahüratın Geleneklerle İlişkisi, Milli Folklor, 2009, Y. 21, S. 82, s. 159.

17 Bilir, Pervin/Avgın, Anıl: "Ceza Alan Futbol Taraftarlarının Şiddete Yönelik Davranışlarının İncelenmesi: Adana İli Örneği”, Spor ve Performans Araştırmaları Dergisi, s. 236.

18 Kıraç, Erkan: "Futbolda Şiddet ve Çıkış Yolları Üzerine Bir Deneme”, http://www.sporhukuku.org/futbolda-siddet-ve-cikis-yollari-uzerine-bir-deneme/, s. 3, Erişim Tarihi: 27 Aralık 2019 
miş ${ }^{19}$ ve akabinde 14/04/2011 tarihinde yürürlüğe giren 6222 say1lı Sporda Şiddet ve Düzensizliğin Önlenmesine Dair Kanun ihdas edilmiştir ${ }^{20}$. İşbu kanun da 10/12/2011 tarihli ve 6259 sayılı kanun ${ }^{21}$ ile değişikliğe uğratılmış ve son halini almıştır. Kanunun 1. maddesine göre işbu kanunun amacı; müsabaka öncesinde, esnasında veya sonrasında spor alanları ile bunların çevresinde, taraftarların sürekli veya geçici olarak gruplar halinde bulundukları

19 Hürmüz, Peyman: 6222 Say1l Sporda Şiddet ve Düzensizliğin Önlenmesine Dair Kanun Yasak Filler ve Ceza Hükümleri, Adalet Yayınevi, 1. Bask1, Ankara 2016, s. 169-170; 5149 sayılı kanunun hangi noktalarda eksik kaldığına ilişkin olarak 6222 sayılı Kanun'un genel gerekçesi incelenebilir.

20 Yurtcan, Erdener: Sporda Şiddetin ve Düzensizliğin Önlenmesi Kanunu ve Yorumu6222 sayılı Yasaya Göre Yeniden Yazılmış, Adalet Yayınevi, 2. Baskı, Ankara 2011, s. $1-5$.

$21 \quad 6250$ Sayılı Kanunun Genel Gerekçesi:

...Bilindiği üzere suç işleyen kişi hakkında işlenen fiilin ağırlığıyla orantılı ceza veya güvenlik tedbirine hükmolunması ceza hukukunun genel ilkelerindendir. Ceza yarg1laması alanında temel kanun olan 5237 sayılı Türk Ceza Kanununun 3 üncü maddesinde de bu ilkeye yer verilmiştir. Bu ilke gereğince işlenen suça verilecek cezanın, fiilin ağırlığı ile orantılı olmasının yanı sıra diğer kanunlarda öngörülen suçlara verilen cezalar dikkate alınmak suretiyle adil ve hakkaniyete uygun olarak belirlenmesi gerekmektedir... Öte yandan şike suçu ve teşvik primi bakımından cezalarda önemli ölçüde indirime gidilmiş olmasına karşın 11 inci maddeye eklenen dokuzuncu fikrayla şike suçu ve teşvik primi bakımından hükmün açıklanmasının geri bırakılması kararı verilemeyeceği ve verilen hapis cezasının seçenek yaptırımlara çevrilemeyeceği veya ertelenmeyeceği düzenlenmiștir. $\mathrm{Bu}$ düzenleme șike ve teşvik primi suçu bakımından netice ceza ne olursa olsun fail hakkında verilen hapis cezasının infaz edileceği anlamına gelmektedir. Netice ceza iki yıla kadar olan suçlarda hükmün açıklanmasının geri bırakılması veya erteleme müessesinin uygulanabildiği dikkate alındığında yapılan yeni düzenlemenin şike ve teşvik primi suçuyla mücadele bakımından taşıdığı önem anlaşılacaktır.

6259 sayılı Sporda Şiddet ve Düzensizliğin Önlenmesine Dair Kanunda Değişiklik Yapılması Hakkında Kanun, yayımlanmadan önce (6250 sayısı ile) dönemin Cumhurbaşkanı Abdullah Gül'e gönderilmiş ve bu kanun dönemin Cumhurbaşkanı tarafindan “...Bu itibarla, incelenen kanunla öngörülen değişikliklerin, ölçülülük ve caydırıcılık gibi ceza hukukunun temel prensiplerini etkisiz kılacağı ve yukarıda belirtilen sakıncaları doğurabileceği düşünülmektedir. Diğer taraftan, 6222 sayll Kanunda değişiklik öngören bu kanunun gerekçesinde, yapılan değişikliklerin, diğer kanunlarda öngörülen suçlara verilen cezalar dikkate alınmak suretiyle adil ve hakkaniyete uygun cezalar belirlenmesi amacıyla gerçekleştirildiği belirtilmekte ise de, kamuoyunda, genel ve gereklilikten doğan bir düzenleme olmaktan ziyade, halen yürütülmekte olan bir soruşturma kapsamında bulunan kişilere yönelik özel bir düzenleme olduğu intibaını uyandirdiğg, bu durumun da değiş̧ikliğin esas amacı dışında özel bir saikle hazırlandiğ eleştirilerine sebebiyet verdiği görülmektedir." gerekçesiyle Türkiye Büyük Millet Meclisine geri gönderilmiştir. Geri gönderilen bu kanun aynen kabul edilerek 6259 sayısı ile yayımlanmış ve 6222 sayılı Kanunda böylelikle değişiklik yapılarak cezalarda indirime gidilmiştir. 
yerlerde veya müsabakanın yapılacağı yere gidiş ve geliş güzergâhlarında şiddet ve düzensizliğin önlenmesidir.

6222 sayılı Sporda Şiddet ve Düzensizliğin Önlenmesine Dair Kanun 'amaç, kapsam ve tanımlar' başlıklı birinci bölüm, 'genel hükümler' başlıklı ikinci bölüm, 'yasak fiiller ve ceza hükümleri' başlıklı üçüncü bölüm ve 'çeşitli hükümler' başlıklı dördüncü bölüm olmak üzere toplam dört bölümden oluşmaktadır. Kanunun 'yasak fiiller ve ceza hükümleri' başlıklı üçüncü bölümünde, şike ve teşvik primi, spor alanlarına sokulması yasak maddeler, spor alanlarına yasak madde sokulması ve müsabaka düzeninin bozulması, hakaret içeren tezahürat, spor alanlarına usulsüz seyirci girişi, yasak alanlara girme, spor alanlarında taşkınlık yapılması ve tesislere zarar verilmesi gibi yasak fiiller ve bu fiillerin karşıllğında uygulanacak olan yaptırımlar düzenlenmiştir ${ }^{22}$. Her ne kadar atıf yapılan bu yasak fiillerin düzenlendiği madde metinleri incelendiğinde, maddede düzenlenen fiillerin failinin herkes olabileceği kanaatine ulaşılmaktaysa da, bilhassa 'hakaret içeren tezahürat' başlıklı 14. madde için böyle bir çıkarımda bulunmak, madde başlığından da anlaşılacağı üzere mümkün değildir. Diğer taraftan ifade etmek gerekir ki aşağıda ayrıntıları ile açıklanacağı üzere müsabaka alanlarındaki sporcuların 14. maddenin 2. fikrası kapsamında değerlendirilmeyen hakaret eylemleri bakımından 6222 sayılı Kanunda bir düzenleme bulunmamaktadır ve dolayısıyla böyle bir durumun varlığı halinde genel hükümlere göre soruşturma yürütülecek ve 5237 sayılı Türk Ceza Kanunu'nun ilgili hükümleri tatbik edilecektir. Yine kanunun 'spor alanlarında taşkınlık yapılması ve tesislere zarar verilmesi' başlıklı 17 . maddesinde yapılan atıf nedeniyle spor alanlarında kasten yaralama ve mala zarar verme suçları bakımından 5237 sayılı Türk Ceza Kanunu'nun ilgili hükümleri tatbik edilecektir.

6222 sayılı Sporda Şiddet ve Düzensizliğin Önlenmesine Dair Kanunun üçüncü bölümünde düzenlenen yasak fiillerle ilgili olarak benzer düzenlemelere Türkiye Futbol Federasyonu Futbol Disiplin Talimatında da yer verilmiştir ${ }^{23}$. Fakat ifade etmek gerekir ki çalışmamızın konusu esasen Kanunun üçüncü bölümünde düzenlenen yasak fiillerin -bilhassa 14. maddede düzenlenen hakaret içeren tezahürat ve 17. maddede düzenlenen spor alanlarında taşkınlık yapılması ve tesislere zarar verilmesi eylemlerinin- ceza hukukunun konusunu oluşturup oluşturamayacağına ilişkin olup konunun disiplin hukuku boyutu çalışmamız kapsamında değildir. Ancak önemle belirtmek gerekir ki 6222 say1lı Kanunun 19. maddesi "Bu kanuna göre bir spor

22 Gerçeker, Hasan: Spor Hukuku, Seçkin Yayıncılık, 1. Baskı, Ankara 2016, s. 146.

23 Özelçi, s. 350. 
kulübüne veya spor kulübünün mensubuna ceza verilmesi, bu kulübün bağl1 olduğu federasyonun yaptırım uygulama yetkisini ortadan kaldırmaz." Şeklinde hüküm altına alınmış olup işbu hüküm hiç şüphesiz ki yasak fiil olarak tabir edilen söz konusu eylemlerin hem ceza hukuku kapsaminda hem de disiplin hukuku kapsamında değerlendirilmesi gerekliliğini ortaya koymaktadır. Çalışmanın ilerleyen bölümlerinde farklı başlıklar altında bu hususlar ile ilgili olarak ayrıntılı açıklamalara yer verilecek ve ilgili yerlerde çalışmanın boyutu elverdiği ölçüde yargı uygulamalarına ve doktrindeki görüşlere de atıf yapılarak konu ile ilgili kanaatimiz belirtilecektir.

\section{MÜSABAKA ALANLARINDAKí ${ }^{24}$ SPORCULARIN HAKARET IÇEREN EYLEMLERININ TÜRK CEZA HUKUKU AÇISINDAN DEĞERLENDİRILMESI}

6222 say1l Sporda Şiddet ve Düzensizliğin Önlenmesine Dair Kanunun 'hakaret içeren tezahürat' başlıklı 14. maddesi “(1) Spor alanlarında veya çevresinde taraftarların grup halinde veya münferiden belirli bir kişiyi hedef veya muhatap alıp almadığına bakılmaksızın duyan veya gören kişiler tarafından hakaret olarak algılanacak tarzda aleni olarak söz ve davranışlarda bulunmaları halinde, fiilleri daha ağır cezayı gerektiren başka bir suç oluşturmadığ 1 takdirde ${ }^{25}$, şikayet şartı aranmaksızın, failler hakkında onbeş günden az olmamak üzere adli para cezasına hükmolunur ${ }^{26}$. (2) Spor alanlarında veya çevresinde toplum kesimlerini din, dil, ırk, etnik köken, cinsiyet veya mezhep farkı gözeterek hakaret oluşturan söz ve davranışlarda bulunan kişi, fiili daha ağır cezayı gerektiren başka bir suç oluşturmadı̆̆ı takdirde, üç aydan bir yıla kadar hapis cezası ile cezalandırılır. (3) Birinci ve ikinci fikra-

\footnotetext{
$24 \mathbf{6 2 2 2}$ sayılı Sporda Şiddet ve Düzensizliğin Önlenmesine Dair Kanun-Madde 3:

f) Müsabaka alanı: Spor müsabakasının yapılmasına tahsis edilen alanı,

g) Spor alanı: Spor müsabakalarının veya antrenmanların gerçekleştirildiği alanlar ile seyircilere ait seyir alanları, sporculara ait soyunma odası ve bu Kanunun uygulanması kapsamında spor yapmaya elverişli alanları, ... ifade eder.

25 Hürmüz, s. 55; Tabel, Taner: "6222 Say1lı Kanunun Uygulama Sorunları ve Çözüm Yolları Paneli”, İstanbul 2013, http://olimpiyatkomitesi.org.tr/editorimages/seminer/ Spor_Hukuku_2014_pdf. s. 32, Erişim Tarihi: 2 Ocak 2019

26 Maddenin 1. fikrasında hüküm altına alınan eylem 5237 sayılı Türk Ceza Kanunu'nun 75. maddesi uyarınca önödemeye tabidir. "6222 sayılı Kanun'un 14/1. maddesinde düzenlenen suçun önödemeye tabi olması nedeniyle sanığa soruşturma aşamasında usulüne uygun olarak önödeme ihtaratında bulunulduğu halde, sanığın yasal süresi içinde herhangi bir ödeme yapmaması karşısında, yargılamaya devamla esasa ilişkin karar verilmesi gerekirken yazılı şekilde düşme kararı verilmesi bozmayı gerektirmiştir." (Yargıtay 19. Ceza Dairesi, 20/04/2016, 2015/13867 Esas, 2016/16041 Karar, www.kazanci.com)
} 
larda tanımlanan suçların yazılı pankart taşınması veya asılması ya da duvarlara yazı yazılması suretiyle işlenmesi halinde, verilecek ceza yarı oranında $\operatorname{artır}_{1} 1 \mathbf{r}^{27}$." şeklinde hüküm altına alınmıştır ${ }^{28}$. İşbu madde 3 fikradan oluşmakta olup, 1. fikrada taraftarların hakaret içeren eylemlerine yer verilmiş, 2. fikrada ayrımcılık içeren hakaret eylemleri bakımından düzenleme yapılmış, 3. fikrada ise 1. ve 2. fikralardaki eylemlerin nitelikli haline yer verilmiştir $^{29}$. Öncelikle ifade etmek gerekir ki madde metninin 1. fikrasındaki 'fiilleri daha ağır cezayı gerektiren başka bir suç oluşturmadığı takdirde' ibaresi hakaret olarak algılanacak söz ve davranışların belirli bir kişiyi muhatap alması halinde 5237 sayılı Türk Ceza Kanunu'nun 125. maddesinde hüküm altına alınan 'hakaret' suçuna ilişkin hükümlerin uygulanması gerektiğine işaret etmektedir. Zira 6222 sayılı Kanunun 14. maddesinin 1. fikrasında yer alan yaptırım onbeş günden az olmamak üzere adli para cezas iken, 5237 sayılı Kanunun 125. maddesinde yer alan yaptırım üç aydan iki yıla kadar hapis veya adli para cezası olarak belirlenmiştir. Hal böyleyken kanaatimizce hakaret olarak algılanacak söz ve davranışların belli bir kişiyi muhatap alması halinde fail hakkında Türk Ceza Kanunu'nun 44. maddesinde düzenlenen içtima ${ }^{30}$ hükümleri de dikkate alınarak Türk Ceza Kanunu'nun 125. maddesinde hüküm altına alınan hakaret suçundan yargılama yapılması gerekecektir. Kaldı ki uygulama da bu yöndedir. Benzer şekilde madde metninin 2. fikrasındaki 'fiili daha ağır cezayı gerektiren başka bir suç oluşturmadığı takdirde' ibaresi de failin fiilinin Türk Ceza Kanunu'nun 216. maddesinin 2. fikrası kapsamında kalması halinde, işbu hükmün tatbik edilmesi gerektiğini ortaya koymaktadır. Zira 5237 sayılı Türk Ceza Kanunu'nun 216. maddesinin 2. fikrası "Halkın bir kesimini, sosyal sınıf, ırk, din,

27 “5149 sayılı Kanunda özel olarak düzenlenmediğinden, hareket ifadesinin geniş anlamda yorumlanması suretiyle, basılı ve yazılı belgeler ile afiş, pankart ya da benzeri araçların kullanılarak maddede yasaklanan fiillerin işlenmesinin de madde kapsamında cezalandırılmayı gerektirdiği ileri sürülmüştü." (Yurtcan, Erdener: Sporda Şiddet ve Düzensizliğin Önlenmesi Kanunu ve Yorumu, Kare Yayınları, 1. Bask1, İstanbul 2006, s. 29)

28 Burada Türkiye Futbol Federasyonu Futbol Disiplin Talimatı'nın 53. maddesine atıf yapmanın yararlı olacağı kanaatindeyiz. Zira atıf yapılan hükme göre "Stadyumlarda topluluk halinde söz veya hareketlerle ya da benzeri araçlar ile aşağılayıcı, tahrik veya taciz edici nitelikte tezahüratta bulunulması, devamlılık kıstası uygulanmaksızın yasaktır. Profesyonel lig müsabakalarında çirkin ve kötü tezahüratta bulunulması halinde kulüplere Ek-1 ve Ek-2, Türkiye Kupası müsabakalarında ise Ek-3'te yer alan tablolara göre ceza verilir."

Göktürk, Neslihan: Fikri İçtima, Adalet Yayınevi, 1. Baskı, Ankara 2013, s. 58. 
mezhep, cinsiyet veya bölge farklılığına dayanarak alenen aşağılayan kişi, altı aydan bir yıla kadar hapis cezası ile cezalandırılır." şeklinde hüküm altına alınmış olup, hiç şüphesiz ki mezkur madde metnindeki yaptırım, 6222 sayılı Kanunun 14. maddesinin 2. fikrasındaki yaptırıma kıyasla daha ağırdır ${ }^{31}$.

Diğer taraftan önemle ifade etmek gerekir ki, atıf yapılan madde metninin başlığı ile içeriği örtüşmemektedir. Zira madde metninin başlığının 'hakaret içeren tezahürat' olması maddenin 2. fikrasında hüküm altına alınan eylemin failinin de yalnızca taraftar olabileceği düşüncesini uyandırmaktadır. Hiç şüphesiz ki tezahürat ${ }^{32}$ eylemi taraftarlarca icra edilen bir eylem olup, maddenin birinci fikrasındaki eylemin faili de ancak taraftar olabilmektedir $^{33}$. Oysa maddenin ikinci fikrasında hüküm altına alınan eylem bak1-

31 "Şen, Ersan: "6222 Sayılı Kanun ve Sporda Ceza Sorumluluğu", http://www.haber7.com/yazarlar/prof-dr-ersan-sen/1692923-6222-sayili-kanun-vesporda-ceza sorumluluğu, Erişim Tarihi: 4 Ocak 2019; Aynı husus ile ilgili olarak doktrinde Doğan ise "6222 say1lı Kanun m.14/2 de yer alan suç ile TCK m. 216'da yer alan halkı kin ve düşmanlığa tahrik veya aşağılama suçu arasında gerek yaptırım gerekse suç tanımı itibari ile paralellik bulunmaktadır. 6222 sayılı Kanun m.14/2 de yer alan suçun yaptırımı altı aydan bir yıla iken, TCK m. 216/2 de yer alan suçun yaptırımı üç aydan bir yıla kadar hapis cezası olarak düzenlenmiştir. Hakaret içeren tezahürat eylemleri bakımından, yaptırımının daha ağır olmasına rağmen özel kanun niteliğinde olması nedeniyle 6222 sayılı Kanun uygulama alanı bulacaktır." şeklinde ifadelere yer vermiştir. (Karakaş Doğan, s. 8) Kanaatimizce yukarıda atıf yapılan görüşe katılmak mümkün değildir. Öncelikle ifade etmek gerekir ki yukarıda yazar yaptırımlar bakımından hataya düşmüştür. Zira 6222 sayılı Kanunun 14. maddesinin 2. fikrasında yer alan suçun yaptırımı üç aydan bir yıla kadar hapis iken, Türk Ceza Kanunu'nun 216. maddesinin 2. fıkrasında yer alan suçun yaptırımı altı aydan bir yıla kadar hapis cezasıdır. Dolayısıyla yazarın "Hakaret içeren tezahürat eylemleri bakımından, yaptırımının daha ağır olmasına rağmen özel kanun niteliğinde olması nedeniyle 6222 sayılı Kanun uygulama alanı bulacaktır" şeklindeki tespitine katılmak hukuken mümkün değildir. Kaldı ki gerek madde metnindeki "fiili daha ağır cezayı gerektiren başka bir suç oluşturmadığı takdirde" ifadesi gerekse 5237 say1lı kanunun 'fikri içtima' başlıklı 44. madde düzenlemesi işbu görüşün hukuken kabul edilebilir mahiyette olmadığını ispatlamaya yetmektedir. Kanaatimiz, 216. maddenin 2. fikrası kapsamında kalan bir eylemin varlığı halinde işbu hükmün tatbik edilmesi gerektiği yönündedir.

32 Tezahürat: bağırıp çağırarak, alkışlayıp tempo tutarak yapılan gösteri. (http://www.tdk.gov.tr, Erişim Tarihi: 21 Aralık 2019)

33 Maddenin 1. fikrasındaki eylemin failinin yalnızca taraftar olabileceği sonucuna, madde gerekçesinde de ulaşmak mümkündür. Anılan fikra gerekçesi "Birinci fikrada, taraftarların grup halinde veya münferiden belirli bir kişiyi hedef veya muhatap alıp almadığına bakılmaksızın duyan kişilerin rencide olmasını sağlayacak tarzda aleni olarak söz ve davranışlarda bulunmaları halinde, fiilleri daha ağır cezayı gerektiren başka bir suç oluşturmadığı takdirde, failler hakkında uygulanacak ceza hükmü belirtilmiştir. Söz konusu suçun takibinde şikayet şartı aranmaması öngörülmüştür. Suçun işlenmesi için fiilin spor 
mından failin yalnızca taraftar olabileceğini söylemek mümkün değildir. Hal böyleyken, 14. maddenin başığııın, madde içeriğini kapsamadığı izahtan vareste olup, bu durum kanun yapma tekniği açısından kabul edilebilir mahiyette değildir. Kanaatimiz, ya madde içeriği ile bağdaşır mahiyette bir madde başlığının tanzim edilmesi ya da maddenin fail bakımından özellik arz etmeyen 2. fikrasının madde dışına çıkarılması gerektiği yönündedir.

Yukarıda ifade edildiği üzere 6222 sayılı kanunun 14. maddesinin 1. fikrasında düzenlenen eylemin faili gerek madde başlığındaki tezahürat ifadesinden gerekse madde metni ve gerekçesindeki taraftar ibaresinden ve gerekse Yargıtay'ın yerleşmiş içtihatlarından ${ }^{34}$ anlaşılacağı üzere yalnızca taraftar olabilir. Doktrinde bu husus ile ilgili olarak Tabel "6222 sayılı Kanun m.14/1'de yer alan 'taraftarların grup halinde veya münferiden' şeklindeki tanıma göre, hakaret içeren tezahürat suçunun faili ancak taraftarlar olabilir. Taraftarların grup halinde veya tek başlarına suçun fail olması mümkündür. Taraftar olmayan kişilerin örneğin stad çalışanlarının birbirine yönelik hakaretleri madde kapsamında olmayıp genel hükümlere tabidir." şeklinde ifadelere yer vermiştir. İşbu düzenlemeye göre taraftarların hakaret içeren eylemleri şikâyet şartı aranmaksızın soruşturulacaktır ${ }^{36}$. Oysa müsa-

alanlarının içerisinde, çevresinde veya herhangi başka bir yerde gerçekleştirilmesinin bir önemi bulunmamaktadır. Kanunun amaç ve kapsam maddeleri dikkate alındığında taraftarların sürekli veya geçici olarak gruplar halinde bulundukları yer ve mekanlarda veya müsabakanın yapılacağı yere gidiş ve geliş güzergahlarında da bu işlenebilecektir." şeklindedir.

“...6222 Say1lı Kanun'unun 14/1. maddesi açısından korunan hukuki yarar, spor alanlarında gerek kişilerin şeref ve haysiyetinin gerekse toplumu oluşturan bireylerin ortak ahlak duygusunun korunmasıdır. Bu düzenlemeyle, taraftarların spor alanlarında veya çevresinde çoğu zaman koro şeklinde rakip takıma, kulübe veya onun taraftarlarına karşı duyanları utandıracak tarzda tezahürat yapanlar cezalandırılmaktadır. Yine bu suç bakımından failin cezalandırılabilmesi için, söylenen sözlerin veya yapılan davranışların duyan veya gören kişiler tarafından hakaret olarak algılanacak tarzda ve aleni bir şekilde gerçekleştirilmesi gerektiğinden, bu husus, toplumun genel değer yargıları ve ortak edep duygusuna göre belirlenecektir. Fikri içeriğe sahip olmayan, kötü bir özelliği veya huyu ifade eden sözler ve küfür niteliğinde söz söylemek ve davranışlarda bulunmak suretiyle kötü tezahürat bu suçu oluşturur, rakip takımın moralini bozucu nitelikte ve fakat kendi takımlarına destek mahiyetindeki hicvedici sözler ise bu suçu oluşturmamaktadır." (Yargitay 19. Ceza Dairesi, 17/05/2016, 2015/33944 Esas, 2016/18153 Karar, www.kazanci.com)

Tabel, s. 36.

36 "Taraftarların grup halinde veya tek başlarına, spor alanlarında veya çevresinde, karşılaşma öncesi, sırası ve sonrasında alenen hakaret içeren, kötü ve çirkin tezahüratlarda bulunması halinde, şikayet şartı gerçekleşmemiş olduğundan TCK m.125 uyarınca failler hakkında yargılama yapılamamaktadır... Oysa bu eylemler duyan veya gören 
baka alanlarındaki sporcuların, 6222 sayılı kanunun uygulama alanı olan yer ve zamanda ${ }^{37}$, gerek diğer sporculara, gerek hakem ve diğer görevlilere, gerekse taraftarlara yönelik hakaret içeren ve 14. maddenin 2. fikrası kapsamında değerlendirilemeyecek olan eylemleri 6222 say1lı Kanunun kapsamına girmemektedir. Dolayısıyla sporcuların bu nitelikteki eylemleri bakımından 6222 sayılı Kanun kapsamında Spor Savcılığı tarafından şikâyet şartı aranmaksızın soruşturma başlatılması hukuken mümkün değildir. Kanaatimizce böyle bir durumun varlığ halinde, genel hükümlere göre soruşturma başlatılacak ve 5237 sayılı Türk Ceza Kanunu'nun bilhassa 'hakaret' başlıklı 125. maddesi ve diğer ilgili maddeler somut olaya tatbik edilecektir.

Sporcuların, kamu görevlisi sayılan hakem ${ }^{38}$ dışındaki diğer şahıslara, örneğin diğer sporculara ya da taraftarlara yönelik hakaret içeren eylemleri

kişilerde hakarete uğradıkları algısını yaratmakta ve alenen işlenmektedir. Bu boşluğu doldurmak üzere, 6222 sayılı Kanun'un yasak fiiller ve ceza hükümleri başlıklı üçüncü bölümünde ve 'hakaret içeren tezahürat' ismi ile özel bir suç tipi yaratılmıştır." (Koca, Mahmut: 6222 Sayılı Sporda Şiddet ve Düzensizliğin Önlenmesine Dair Kanunda Düzenlenen Suçlar ve Kabahatler, Gazi Üniversitesi Türk Ceza Hukuku Uygulama ve Araştırma Merkezi, Sporda Şiddet ve Düzensizliğin Önlenmesi Kolokyumu, Seçkin Yayıncılık, Ankara 2012, s. 69; Karakaş Doğan, s. 83-106); “Aynı şekilde şikayet olmadığı için, TCK'nun 125. maddesi uyarınca failler hakkında işlem yapılamadığı takdirde, hakaret içeren söz ve davranışların belli bir kişiyi hedef veya muhatap alıp almadığına bakılmadan uygulanması söz konusu olduğundan, anılan kanunun 14/1. maddesi uygulanacaktır." (Hürmüz, s. 55)

376222 sayılı Kanun'un uygulama alanı olan yer ve zaman ile ilgili olarak Yargitay 19. Ceza Dairesi'nin 30/10/2017 tarihli, 2016/15044 Esas ve 2017/8814 Karar sayılı kararına atıf yapmak gerekir. Karar aynen şu şekildedir: "Buna göre spor alanları; sportif faaliyetlerin icra edildiği yerlerden müsabaka ve antrenman alanlarının yanı sira seyircilere ait seyir alanlarını, sporculara ait soyunma odalarını ve 6222 Sayılı Kanun'un uygulanması kapsamında spor yapmaya elverişli alanları, müsabaka alanı; spor müsabakasının yapılmasına tahsis edilen alanı, spor müsabakası; federasyonların düzenlediği veya düzenlenmesine izin verdiği ya da katkıda bulunduğu her türlü sportif karşılaşma ve yarışmayı ifade eder. Kanunun amaç ve kapsamı dikkate alınarak, müsabaka öncesi; takımların veya seyircilerin stadyum sınırları içine girmelerinden itibaren müsabakanın başlama anına kadar geçen süreyi, müsabaka esnası; müsabakanın başlama anından itibaren bitiş anına kadar geçen süreyi, müsabaka sonrası; müsabakanın bitiş anından takımların ve seyircilerin stadyum sınırları dışına tamamen çıktıkları ana kadar geçen süreyi, yeşil zemin; müsabaka öncesinde, esnasında, devre arasında ve müsabaka sonunda hakemin ve ilgili federasyon temsilcinin izin verdiği kişilerin girebildiği alanı, saha içi; müsabaka için seyircilerin kabulüne başlanmasından itibaren müsabaka sonrası tamamen tahliyesine kadarki zaman zarfında yeşil zemin ile seyircilere ait seyir alanları arasında kalan akredite alanı ifade eder." (Yargitay 19. Ceza Dairesi, 30/10/2017, 2016/15044 Esas, 2017/8814 Karar, www.kazanci.com) 
ancak hakarete maruz kalan kişinin şikâyetçi olması durumunda genel hükümlere göre soruşturma konusu olabilecektir. Hakaret suçu 5237 sayılı Türk Ceza Kanunu'nun 125. maddesinde ${ }^{39}$ hüküm altına alınmış ve aynı kanunun 131. maddesinin 1. fikrasında ise hakaret suçu ile olarak "Kamu görevlisine karşı görevinden dolayı işlenen hariç; hakaret suçunun soruşturulması ve kovuşturulması, mağdurun şikayetine bağlıdır." düzenlemesine yer verilmiştir ${ }^{40}$. Hal böyleyken, sporcular tarafından 6222 sayılı Kanunun uygulama alanı olan yer ve zamanda, 14. maddenin 2. fikrası kapsamında

(1) c) Kamu görevlisi deyiminden; kamusal faaliyetin yürütülmesine atama veya seçilme yoluyla ya da herhangi bir surette sürekli, süreli veya geçici olarak katılan kişi,.. anlaşılır.

6222 sayılı Sporda Şiddet ve Düzensizliğin Önlenmesine Dair Kanun-Madde 20:

(1) Spor müsabakalarında görev yapan hakem, gözlemci ve temsilciler bu görevleriyle bağlantılı olarak kendilerine karşı işlenen suçlar bakımından kamu görevlisi sayılır.

3289 Sayılı Gençlik ve Spor Hizmetleri Kanunu-Ek Madde 1:

(1) Kamu hizmeti olarak yapılan gençlik ve spor organizasyonlarında görevlendirilen geçici görevliler, o organizasyonla ilgili görevlerini fiili olarak yürüttükleri süre içinde veya bu görevi ile ilgili ilişkileri sırasında kamu görevlisi sayılır. Ceza kanunlarının uygulanması bakımından, bunların işledikleri suçlarla, bunlara karşı işlenen suçlarda Devlet memurlarına ilişkin hükümler uygulanır.

\section{Sayılı Gençlik ve Spor Hizmetleri Kanunu-Ek Madde 9:}

...Federasyon faaliyetlerinde görevli bulunanlar, görevleriyle bağlantılı olarak işlemiş oldukları suçlar bakımından kamu görevlisi sayılır.

5237 sayılı Türk Ceza Kanunu-Madde 125:

(1) Bir kimseye onur, şeref ve saygınlığını rencide edebilecek nitelikte somut bir fiil veya olgu isnat eden veya sövmek suretiyle bir kimsenin onur, şeref ve saygınlığına saldıran kişi, üç aydan iki yıla kadar hapis veya adlî para cezası ile cezalandırılır. Mağdurun gıyabında hakaretin cezalandırılabilmesi için fiilin en az üç kişiyle ihtilat ederek işlenmesi gerekir.

(2) Fiilin, mağduru muhatap alan sesli, yazılı veya görüntülü bir iletiyle işlenmesi halinde, yukarıdaki fikrada belirtilen cezaya hükmolunur.

(3) Hakaret suçunun;

a) Kamu görevlisine karşı görevinden dolayı,

b) Dini, siyasi, sosyal, felsefi inanç, düşünce ve kanaatlerini açıklamasından, değiştirmesinden, yaymaya çalışmasından, mensup olduğu dinin emir ve yasaklarına uygun davranmasindan dolayı,

c) Kişinin mensup bulunduğu dine göre kutsal sayılan değerlerden bahisle, İşlenmesi halinde, cezanın alt sınırı bir yıldan az olamaz.

(4) Hakaretin alenen işlenmesi halinde ceza altıda biri oranında artırılır.

(5) Kurul hâlinde çalışan kamu görevlilerine görevlerinden dolayı hakaret edilmesi hâlinde suç, kurulu oluşturan üyelere karşı işlenmiş sayılır. Ancak, bu durumda zincirleme suça ilişkin madde hükümleri uygulanır.

Artuk, Mehmet Emin/Gökcen, Ahmet/Yenidünya, Caner: Türk Ceza Kanunu Şerhi, 3. Cilt, Adalet Yayınevi, 2. Bask1, Ankara 2014, s. 4364. 
değerlendirilemeyecek olan hakaret içeren eylemlerin gerçekleştirilmesi halinde, 6222 sayılı Kanun kapsamında soruşturma yapmak hukuken mümkün değildir ve böyle bir durumun varlığ halinde mağdur olan kişinin kamu görevlisi olup olmadığı dikkate alınarak ${ }^{41}$ genel hükümlere göre soruşturma başlatılacaktır. Diğer taraftan sporcuların hakaret içeren eylemleri mağdurun gıyabında gerçekleştirilmiş ise fiilin en az 3 kişiyle ihtilat edilerek işlenmesi $^{42}$ ve eylemin soruşturulabilmesi için yine mağdurun şikâyetçi olması gerekmektedir ${ }^{43}$.

41 Mağdur kamu görevlisi ise şikâyet şartı aranmaksızın soruşturma başlatılacak; kamu görevlisi değilse mağdurun şikayeti üzerine soruşturma başlatılabilecektir. "Sanığın, kaymakamlık tarafından düzenlenmiş olan futbol turnuvasındaki maçta oynadığı sırada, maçta hakem olarak görev yapan ve 3289 sayılı Yasanın ek 1.maddesinin yollamasıyla 5237 Sayılı TCK'nun 6.maddesinin 1.fikrasının (c) bendine göre kamu görevlisi sayılan yakınanın kendisine kırmızı kart göstermesi nedeniyle gerçekleştirdiği hakaret eyleminin, aynı yasanın 125.maddesinin 3.fikrasının (a) bendinde düzenlenen "kamu görevlisine karşı görevinden dolayı hakaret" suçunu oluşturduğu ve atılı suçun aynı yasanın 131.maddesinin (1).fikrası uyarınca kovuşturulması ve soruşturulmasının şikâyete bağlı olmadığı gözetilmeden, suçun nitelendirilmesinde yanılgıya düşülerek şikayetten vazgeçme nedeniyle sanık hakkındaki kamu davasının düşürülmesine karar verilmesi bozmayı gerektirmiş üst Cumhuriyet Savcısının temyiz itirazları bu itibarla yerinde görülmüş olduğundan hükmün bu sebepten dolayı isteme aykırı olarak bozulmasına, 14/01/2013 gününde oybirliğiyle karar verildi." (Yargitay 2. Ceza Dairesi, 14/01/2013, 2011/27975 Esas, 2013/9 Karar, www.kazanci.com)

42 Kocaoğlu, Serhat Sinan: Uluslararası (AİHM) ve Ulusal Yargı İçtihatları Çerçevesinde Hakaret Suçu, Seçkin Yayıncılık, 1. Baskı, Ankara 2019, s. 128-131.

43 “...Hakaret suçu mağdurun olmadığı veya mağdurun doğrudan vakıf olamayacağı bir şekilde işlendiğinde gıyapta hakaret suçu oluşmaktadır. Ancak gıyapta hakaret suçunun cezalandırılması için, failin mağdur dışında toplu veya dağınık en az üç kişiyle ihtilat ederek bu suçu işlemesi gerekmektedir. Suçun faili ihtilatı bilerek ve isteyerek gerçekleştirmelidir. İhtilat kişilerle birebir görüşerek gerçekleşebileceği gibi, üç veya daha fazla kişiye mektup göndermek, telefon etmek, SMS veya e-mail göndermek suretiyle de gerçekleştirilebilir. Ancak ihtilat unsurunun gerçekleşmesi için, failin sözleri en az üç kişinin duyabileceği bir ortamda ve şekilde söylemesi yeterli olmayıp, muhatapların bizzat anlamaları ve vakıf olmaları lazımdır." (Yargitay 18. Ceza Dairesi, 30/10/2018, 2016/8367 Esas, 2018/13828 Karar, www.kazanci.com); “....Hakaret huzurda işlenebileceği gibi, gıyapta da işlenebilir. Gıyapta hakaretin cezalandırılabilmesi için, mağdurun yokluğunda en az ikiden fazla kişilerle ihtilat edilerek yani en az üç kişinin hakaret sözünü öğrenmiş olması kaydıyla hakaretin yapılması şarttır. Mağdur bu sayıya dâhil değildir. Mağdurun hazır olması halinde gıyapta hakaret den bahsedilemez. Kendileriyle ihtilat edilen kişilerin bir arada bulunmaları ve hakaret sözünü aynı anda öğrenmelerine gerek yoktur. İhtilat aktarma suretiyle gerçekleşmişse hakaret sözlerinin aynı ya da benzer olması aranmalıdır. Fail sözlerini ikiden fazla kişiye söylemekte ya da daha çok kişinin duyabileceği bir yerde konuşmakta ve sözleri başkaları tarafından duyulabilmekte, failde bu durumun bilincinde ise ihtilat oluşmuştur." (Yargitay 15. Ceza Dairesi, 09/11/2015, 2015/8645 Esas, 2015/31012 Karar, www.kazancl.com) 
Yukarıda müteaddit defa sporcuların, 6222 sayılı Kanunun 14. maddesinin 2. fikrası kapsamında değerlendirilemeyecek olan hakaret içeren eylemlerinin genel hükümlere göre soruşturulacağı hususuna değinmiştik. Yaptığımız ayrıntılı açıklamalardan da anlaşılacağı üzere, sporcuların 6222 sayılı Kanunun 14. maddesinin 2. fikrası kapsamında kalan hakaret içeren eylemleri bakımından 6222 sayılı Kanunun ilgili maddesi tatbik edilecek ve spor savcılığı tarafından işbu mevzuat hükümlerine göre soruşturma yürütülecektir. Zira işbu düzenlemenin fail bakımından bir özellik arz etmediği açıktır. Bu husus madde metninin gerekçesinde de "İkinci fikrada, spor alanlarında veya çevresinde toplum kesimlerinin din, dil, ırk, etnik köken veya mezhep farkı gözeterek tahkir edici söz ve davranışlarda bulunan kişiye fiili daha ağır cezayı gerektiren başka bir suç oluşturmadığ takdirde uygulanacak ceza hükmü belirtilmiştir." şeklinde ifade edilmiştir. Buna göre sporcuların, ayrımcılık içeren hakaret eylemlerinin genel hükümlere göre soruşturulamayacağ 1 izahtan varestedir. Nitekim uygulamada da sporcular hakkında ayrımcılık içeren hakaret eylemleri bakımından 6222 sayılı Kanun kapsamında soruşturma yapılmaktadır. Örneğin, 5 Nisan 2012'de Trabzonspor-Fenerbahçe arasında oynanan Spor Toto Süper Final Şampiyonluk Grubu maçı sonrasında Fenerbahçeli futbolcu Emre Belözoğlu'nun, Trabzonsporlu Didier Zokora'ya "irkçı söylemde" bulunduğu gerekçesiyle kamu davası ikame edilmiş, yapılan yargılama neticesinde Emre Belözoğlu hakkında kanunun 14. maddesinin 2. fikrasını ihlal ettiği gerekçesiyle 2 ay 15 gün hapis cezasına hükmedilmiş, işbu hapis cezası hakkında da hükmün açıklanmasının geri bırakılması müessesesi tatbik edilmiş ve bu karar kesinleşmiştir

\section{MÜSABAKA ALANLARINDAKİ SPORCULARIN KASTEN YARALAMA VE MALA ZARAR VERME EYLEMLERININ TÜRK CEZA HUKUKU AÇISINDAN DEĞERLENDİRILMESİ}

\section{A. Kasten Yaralama Eylemlerinin Türk Ceza Hukuku Açısından Değerlendirilmesi}

6222 say1lı Sporda Şiddet ve Düzensizliğin Önlenmesine Dair Kanunun 'spor alanlarında taşkınlık yapılması ve tesislere zarar verilmesi' başlıklı 17. maddesi "(1) Spor alanlarında kasten yaralama suçunun veya mala zarar verme suçunun işlenmesi halinde şikâyet şartı aranmaksızın 26/9/2004 tarihli ve 5237 sayılı Türk Ceza Kanununun ilgili maddelerine göre cezaya hükmolunur. Spor alanları ve bu alanlardaki eşya, mala zarar verme suçu bakımından kamu malı hükmündedir. (2) Birinci fikra kapsamına giren suç- 
ların işlenmesi suretiyle spor alanlarına ve bu alanlardaki eşyaya zarar verilmiş olması halinde, meydana gelen zararların tazmini hususunda zarar veren kişiler ve onların taraftarı olduğu spor kulübü meydana gelen zarardan müteselsilen sorumludur. Zararı gideren spor kulübünün sorumlu taraftarlarına rücu hakkı saklıdır ${ }^{44}$." şeklinde hüküm altına alınmıştır ${ }^{45}$. Atıf yapılan hükümden de anlaşılacağı üzere sporcuların, diğer sporculara, hakeme veya taraftara yönelik kasten yaralama suçunu oluşturan eylemleri 6222 sayıl1 Kanunun 17. maddesinin delaletiyle Türk Ceza Kanunu'nun ilgili hükümlerine göre değerlendirilecektir ${ }^{46}$. Öncelikle ifade etmek gerekir ki sporcular tarafindan diğer sporculara yönelik kasten yaralama fiillerinin 6222 sayılı kanun kapsamında değerlendirilebilmesi için eylemin müsabaka esnasındaki pozisyon gereği yapılan müdahaleler kapsamında olmaması, tasvip edilen sertliği aşmass ${ }^{47}$ yani yaralama kastı ile gerçekleştirilmiş olması gerekir. Zira Yargitay'ın yerleşmiş içtihatlarında da ifade edildiği üzere futbol gibi spor müsabakalarında kasitlı yaralamalar hariç kazaen yaralamalar yönünden müsabaka öncesi oyuncuların rızalarının bulunduğu varsayılır ve bu durum bir hukuka uygunluk nedeni ${ }^{48}$ olarak değerlendirilir ${ }^{49}$. Dolayısıyla böyle bir

44 Kanaatimizce bu düzenleme 5237 sayılı Türk Ceza Kanunu'nun 20. maddesinde "Ceza sorumluluğu şahsidir. Kimse başkasının fiilinden dolayı sorumlu tutulamaz." şeklinde düzenlenen 'ceza sorumluluğunun şahsiliği' ilkesine aykırıdır. 6222 Sayılı Kanunun 17. Maddesinin Gerekçesi:

Birinci fikrada spor alanlarında kasten yaralama suçunun veya mala zarar verme suçunun işlenmesi halinde şikayet şartı aranmaksızın Türk Ceza Kanunu'nun ilgili maddelerine göre cezaya hükmolunacağı düzenlenerek spor alanlarında ve bu alanlardaki eşyanın mala zarar verme suçu bakımından kamu malı hükmünde olacağı belirtilmiştir. İkinci fikrada, birinci fikra kapsamına giren suçların işlenmesi suretiyle spor alanlarına ve bu alanlardaki eşyaya zarar verilmiş olması halinde meydana gelen zararların tazmini hususunda zarar veren kişilerin ve onların taraftarı olduğu spor kulübünün meydana gelen zarardan müteselsilen sorumlu olduğu ve zararı giden kulübün sorumlu taraftarlarına rücu hakkı saklı bulunduğu belirtilmiştir. Uslu, s. 213.

47 Gülşen, Recep: Spor Hukuku, Adalet Yayınevi, 2. Baskı, Ankara 2013, s. 78.

48 Özbek, Veli Özer/Doğan, Koray/Bacaksız, Pınar/Tepe, İlker: Türk Ceza Hukuku Genel Hükümler, Seçkin Yayıncılık, 9. Baskı, Ankara 2018, s. 334-336; Koca, Mahmut/ Üzülmez, İlhan: Türk Ceza Hukuku Özel Hükümler, Adalet Yayınevi, Beşinci Bask1, Ankara 2018, s. 210-211.

49 "Olay günü sanık ile katılanın halı saha maçında karşılıklı olarak futbol oynadıkları, sanığın oyun esnasında havaya yükselen topa doğru yöneldiği ve topu almak isterken kasıtlı bir hareketi olmaksızın katılan B.V'nın yüzüne kafasının gelmesiyle katılanın göz çukuru çevre kemiğinde kırık olacak şekilde yaralandığı, tüm dosya içeriğinden sanığın yaralama kastı ile hareket etmediği ve katılan ile sanığın kazaen çarpışması neticesi katılanın yaralandığı, futbol gibi spor müsabakalarında kasıtlı yaralamalar hariç kazaen 
uyuşmazlığın bulunduğu hallerde sanık hakkında 5271 sayılı Ceza Muhakemesi Kanunu'nun 223. maddesinin 2. fikrasının d bendi ${ }^{50}$ uyarınca beraat hükmü tesis edilmesi gerekir ${ }^{51}$.

Diğer taraftan ilgili düzenlemede bahse konu kasten yaralama suçunun şikayete tabi olmadığı açıkça belirtilmiştir ${ }^{52}$. Oysa 5237 sayılı Türk Ceza

yaralamalar yönünden müsabaka öncesi oyuncuların rızalarının bulunduğu ve TCK'nın 26/2 maddesi gereğince de bu rıza çerçevesinde gerçekleşen yaralanmadan ötürü sorumlu tutulamayacağı anlaşılmıştır." (Yargıtay 12. Ceza Dairesi, 04/12/2013, 2013/ 5763 Esas, 2013/27915 Karar, www.kazanci.com); "Spor müsabakaları hukuka uygunluk nedeni bakımından değerlendirildiğinde; Kanun'un verdiği yetkinin kullanılması bakımından, bir sporcu, ilgili spor kurallarının kendisine verdiği yetkiyi kullanmaktaysa, yaptığ 1 hareketler sonucu bir zarar doğmuş olsa bile bu zarar nedeniyle sporcunun sorumluluğuna gidilmesi mümkün olmayacaktır. Zira oyun kurallarına uygun hareket etmiş olması nedeniyle sporcunun eylemi hukuka uygun kabul edilecektir... Mağdurun rızası ile ilgili hukuka uygunluk nedenine gelince, emredici hukuk kurallarına, ahlak ve kişilik haklarına aykırı olmadığı takdirde, mağdurun rızası eylemi hukuka uygun hale getirecektir. Eylem emredici hukuk kurallarına, ahlaka ve kişilik haklarına aykırı ise, mağdurun rızası olsa bile hukuka uygun hale gelmeyecektir. Spor karşılaşmalarında sporcular, oyun kuralları içerisinde kalması koşuluyla rakiplerinin müdahalelerine izin verdikleri kabul edilmektedir. Burada sporcuların rakiplerine verdikleri izin kendilerini yaralaması konusunda olmayıp, oyun kuralarının izin verdiği müdahalelerdir. $\mathrm{Bu}$ nedenle eylemin oyun kuralları içerisinde kalan bir eylem olduğunun tespiti önemli olacaktır. Zararı göze alma konusuna gelince, spor veya gösteri amaçlı oyun ve yarışmalara katılan kişilerin, katıldıkları oyun ve yarışmalardan doğabilecek yaralanmaları ve benzer sonuçları göze alarak katıldıkları kabul edilir. Burada verilen izinden kasıt oyunda yaralanmaya açıkça izin değil, yarışmalardan doğabilecek yaralanma ve benzer sonuçlarını görüp göze alıp oyuna ve yarışmaya katılmasıdır. Sporcu oyuna ve yarışmaya katılırken, oyun kuralları çerçevesinde meydana gelebilecek normal yaralanmalara izin verdiğinin kabulü gerekir, yoksa oyun kurallarına uymayan eylemlerle karşıdaki sporcuya verilen zararlar için izinden bahsedilmesi mümkün olmayıp söz konusu eylem sporcunun kişilik haklarına yapılan bir saldırı olarak kabul edilmesi gerekmektedir." (Yargitay Hukuk Genel Kurulu, 06/11/2013, 2013/4-364 Esas, 2013/1543 Karar, www.kazanci.com)

$50 \quad 5271$ sayılı Ceza Muhakemesi Kanunu-Madde 223/2-d:

(2) Beraat karar1;

d) Yüklenen suçun sanık tarafından işlenmesine rağmen, olayda bir hukuka uygunluk nedeninin bulunması.. hallerinde verilir.

51 "Dosya içeriğine göre; olayın halı sahada futbol oynandığı sırada kaleye şut çekilmesi sonucu gerçekleştiği dikkate alındığında sanık hakkında 5271 sayılı CMK'nın 223/2-d maddesi gereğince yüklenen suçun sanık tarafindan işlenmesine rağmen, olayda bir hukuka uygunluk nedeninin bulunması gerekçesiyle beraat kararı verilmesi gerektiği gözetilmeden 223/2-b. maddesi gereğince beraat kararı verilmesi bozmayı gerektirmiştir." (Yargitay 12. Ceza Dairesi, 19/04/2013, 2012/17736 Esas, 2013/10604 Karar, www.kazanci.com)

52 "18.12.2011 tarihinde Fenerbahçe - Trabzonspor takımları arasında yapılan futbol müsabakasının öncesinde fenerium alt tribününde yer alan sanığın elinde bulunan cep 
Kanunu'nun kasten yaralama suçunu düzenleyen 86. maddesinin ${ }^{53}$ 2. fikrasında kasten yaralama fiilinin kişi üzerindeki etkisinin basit bir tıbbî müdahaleyle giderilebilecek ölçüde hafif olması hâlinde mağdurun şikâyeti üzerine soruşturma yapılabileceği düzenlenmiştir ${ }^{54}$. Hal böyleyken, 6222 sayıl1 Kanunun 17. maddesindeki düzenlemenin, 5237 sayılı Kanunun 86. maddesinin 2. fikrasındaki şikâyet şartını bertaraf edici ve bu haliyle sporda şiddet ve düzensizliğin önlenmesi amacina hizmet eder nitelikte bir düzenleme olduğu söylenebilir. Burada şu hususa dikkat çekmekte de yarar vardır. Yukarıda atıf yapılan ilgili hükümde gerek kasten yaralama gerekse mala zarar verme suçunun spor alanlarında işlenmesi hali düzenlenmiştir. 6222 sayılı Kanunun 'tanımlar' başlıklı 3. maddesinin g bendinde spor alanı "spor müsabakalarının veya antrenmanların gerçekleştirildiği alanlar ile seyircilere ait seyir alanlar1, sporculara ait soyunma odas1 ve bu Kanunun uygulanmas1 kapsamında spor yapmaya elverişli alanlar” şeklinde tanımlanmıştır.

telefonu 1sınmakta olan Trabzonsporlu futbolcuların üzerine atıp isabet ettirememesi biçiminde açıklanan eylemde, 6222 Sayılı Kanun'un 17/1. maddesi uyarınca spor alanlarında işlenen kasten yaralanma suçunun şikayete tabi olmaması ve saldırı amacıyla yapılmış olmasa bile fiilen saldırıda kullanılmaya elverişli suça konu aletin 5237 Sayılı Türk Ceza Kanunu'nun 6/1-f-4 hükmü kapsamında silah olarak kabulünde zorunluluk bulunması sebepleriyle somut olayda bu suçtan mahkumiyet hükmü kurulması gerektiği halde, mahkemece, yanlış nitelendirmede bulunularak şikayet yokluğu sebebiyle düşme kararı verilmesi hukuka aykırı olup, bozmayı gerektirmiştir." (Yargıtay 19. Ceza Dairesi, 27/11/2017, 2016/5114 Esas, 2017/10074 Karar, www.kazanci.com) "Sanığın ve mağdurun karşılıklı müsabaka yapan futbol takımlarının futbolcusu oldukları ve sanığın suçu maç sonunda saha içinde işlemesi nedeniyle 6222 sayılı Kanunun 17/1. maddesi gereğince suçun takibinin şikayete tabi olmadığı gözetilmeden yazılı şekilde karar verilmesi bozmayı gerektirmiştir." (Yargıtay 3. Ceza Dairesi, 02/06/2015, 2015/1217 Esas, 2015/18626 Karar, www.kazanci.com)

$53 \quad 5237$ sayılı Türk Ceza Kanunu-Madde 86:

(1) Kasten başkasının vücuduna acı veren veya sağlığının ya da algılama yeteneğinin bozulmasına neden olan kişi, bir yıldan üç yıla kadar hapis cezası ile cezalandırılır.

(2) Kasten yaralama fiilinin kişi üzerindeki etkisinin basit bir tıbbî müdahaleyle giderilebilecek ölçüde hafif olması hâlinde, mağdurun şikâyeti üzerine, dört aydan bir yıla kadar hapis veya adlî para cezasına hükmolunur. (3) Kasten yaralama suçunun;

a) Üstsoya, altsoya, eşe veya kardeşe karşı,

b) Beden veya ruh bakımından kendisini savunamayacak durumda bulunan kişiye karşı,

c) Kişinin yerine getirdiği kamu görevi nedeniyle,

d) Kamu görevlisinin sahip bulunduğu nüfuz kötüye kullanılmak suretiyle,

e) Silahla, İşlenmesi halinde, şikâyet aranmaksızın, verilecek ceza yarı oranında artırılır

Kocalar, Salih/Biçen, Yunus: Kasten Yaralama Suçu Örneğinde Genel Hükümler, Seçkin Yayıncılık, 1. Baskı, Ankara 2019, s. 145; Zafer, Hamide: Ceza Hukuku Genel Hükümler, Beta Yayınları, 6. Bask1, İstanbul 2016, s. 398. 
Kanaatimiz, spor alanına ilişkin işbu tanım gözetildiğinde yasanın 17. maddesindeki düzenlemenin uygulama alanı bakımından kanunun amacina hizmet etmediği yönündedir. Zira hiç şüphesiz ülkemizdeki sporda şiddet ve düzensizlik eylemleri yoğun olarak spor alanlarının dışında gerçekleşmektedir. Dolayısıyla kanun koyucu tarafindan bu durum dikkate alınarak, madde metnindeki spor alanları ifadesinin hükümden çıkarılması ve bilhassa müsabakanın yapılacağı yere gidiş ve geliş güzergâhları ile taraftarların sürekli veya geçici olarak gruplar halinde bulundukları yerleri kapsayacak şekilde bir düzenleme yapılması gerekir. Kaldı ki uygulamada bu eksiklik, 6222 sayılı kanunun işlevini yerine getirememesine sebep olmakta ve çoğunlukla müsabaka alanına gidiş ve geliş güzergâhlarında gerçekleşen basit tıbbi müdahale ile giderilebilecek kasten yaralama ve mala zarar verme suçlarının şikâyet şartı gerçekleşmediği için soruşturulmamasına yol açmaktadır $^{55}$. Kanaatimizce kanun koyucu tarafindan evleviyetle spor müsabakası ile ilgili olmak şartıyla spor alanı dişında işlenen kasten yaralama ve mala zarar verme suçlarında şikâyet şartının aranmamasına ilişkin yasal düzenleme yapılmalidir.

\section{B. Mala Zarar Verme Eylemlerinin Türk Ceza Hukuku Açısından Değerlendirilmesi}

6222 sayılı kanunun 17. maddesinde hüküm altına alınan bir diğer suç ise mala zarar verme suçudur. Mala zarar verme suçu 5237 sayılı Türk Ceza Kanunu'nun 151. maddesinde hüküm altına alınmıştır ${ }^{56}$. İşbu düzenlemeye göre suçun takibi şikâyete bağlıdır. Oysa 6222 sayılı kanunun 17. maddesinde mala zarar verme suçunun takibinin şikâyete bağlı olmadı̆̆ı açıkça belirtilmiştir. Yine 17. maddede "Spor alanları ve bu alanlardaki eşya, mala zarar verme suçu bakımından kamu malı hükmündedir." şeklinde bir düzen-

55 “...Dosya kapsamına göre sanıkların üzerlerine atılı olay tarihinde bir futbol müsabakası için Bolu iline gelen Kartalspor'a ait bulunan 34 U. 8... plaka sayılı otobüsün camının taşlanmak suretiyle kırılması eyleminin, 6222 sayılı Kanun'un 3/1-g maddesinde tanımlanan 'spor alanı' içerisinde meydana gelmemesi karşısında, anılan mala zarar verme suçunun soruşturulmasının ve kovuşturulmasının şikayete bağlı olduğu gözetilmeksizin yazılı şekilde karar verilmesinde isabet görülmemiştir. " (Yargitay 7. Ceza Dairesi, 09/07/2014, 2014/5611 Esas, 2014/14512 Karar, www.kazanci.com)

(1) Başkasının taşınır veya taşınmaz malını kısmen veya tamamen yıkan, tahrip eden, yok eden, bozan, kullanılamaz hale getiren veya kirleten kişi, mağdurun şikayeti üzerine, dört aydan üç yıla kadar hapis veya adlî para cezası ile cezalandırılır.

(2) Haklı bir neden olmaksızın, sahipli hayvanı öldüren, işe yaramayacak hale getiren veya değerinin azalmasına neden olan kişi hakkında yukarıdaki fikra hükmü uygulanır. 
lemeye yer verilmiştir ${ }^{57} .5237$ sayılı Türk Ceza Kanunu'nun 152. maddesinde de mala zarar verme suçunun nitelikli hallerine yer verilmiş ve suçun nitelikli hallerinin re'sen soruşturulacağı düzenlenmiştir ${ }^{58}$. İlgili maddenin 1. fikrasının a bendinde ${ }^{59}$ kamu malına zarar verilmesi hali de suçun nitelikli hali olarak hüküm altına alınmıştır ${ }^{60}$. Hal böyleyken, her ne kadar 6222 say1lı Kanun'un 17. maddesinde hem kasten yaralama hem de mala zarar verme suçuna iliş̧in olarak şikayet şartı aranmaksızın soruşturma yapılacağ şeklinde bir düzenleme yapılmışsa da, aslında "spor alanları ve bu alanlardaki eşya, mala zarar verme suçu bakımından kamu malı hükmündedir." düzenlemesi ${ }^{61}$, mala zarar verme suçu bakımından şikayet şartını ortadan

57 “Sanı ğın, Elazığ Atatürk Stadyumunda oynanan futbol müsabakasını izledikten sonra, maç içerisinde verdiği kararlar sebebiyle maçın hakemlerine öfkelenerek, konuşmak amacıyla stadyum içerisindeki odalarına giden hakemlerin arkasından ilerlediği sırada, görevlilerin engel olması üzerine çıkan kargaşada, sanığın kapıya yumruk ile vurmak suretiyle yarısı buzlu cam olan kısmını kırarak zarar verdiğinin iddia edildiği olayda, sanık, tanık ve şikayetçi beyanları, görgü tespit tutanağı ile tüm dosya kapsamına göre, eylemin kamu malına zarar verme suçunu oluşturduğuna yönelik mahkemenin kabulünde bir isabetsizlik görülmemiştir." (Yargitay 15. Ceza Dairesi, 25/02/2015, 2014/835 Esas, 2015/21400 Karar, www.kazanci.com); “...Somut olayda; Turgutlu ilçesi Yedi Eylül Stadyumunda oynanan Ulucak Belediye spor ile Kuşadasıspor arasındaki futbol müsabakası sırasında Ulucak Belediye Sporun attığı gole sevinen suça sürüklenen çocuğun protokol tribünü ile kapalı tribün arasında bulunan cama yumruk vurarak camın kırılmasına neden olduğu, bu şekilde üzerine atılı kamu malına zarar vermek suçunu işlediği anlaşılmıştır.” (Yargıtay 15. Ceza Dairesi, 20/05/2014, 2013/18749 Esas, 2014/9780 Karar, www.kazanci.com)

58 Taneri, Gökhan/Kamışlı, Gani: Kişilere Karşı İşlenen Suçlar, Seçkin Yayıncılık, Birinci Bask1, Ankara 2018, s. 913.

595237 sayılı Türk Ceza Kanunu-Madde 152/1-a:

(1) Mala zarar verme suçunun,

a) Kamu kurum ve kuruluşlarına ait, kamu hizmetine tahsis edilmiş veya kamunun yararlanmasına ayrılmış yer, bina, tesis veya diğer eşya hakkında,

İşlenmesi halinde, fail hakkında bir yıldan dört yıla kadar hapis cezasına hükmolunur.

60 “...Bu sebeple suça konu olayda suça sürüklenen çocuğun doğrudan kastının gerçekleşen netice dikkate alınarak 265. madde kapsamındaki kamu görevlisine karşı görevini yapmasını engellemek amacıyla direnme suçunu işlemek olduğunu, olası kastının ise, TCK 152/1.a maddesi kapsamındaki kamu malına zarar verme suçunu işlemek olduğunu kabul etmek gerekir." (Yargitay 16. Ceza Dairesi, 20/11/2017, 2017/2426 Esas, 2017/ 5373 Karar, www.kazanci.com)

61 Bu düzenleme ile ilgili olarak aşağıdaki hükümlere de atıf yapmak gerekir:

3289 sayılı Gençlik ve Spor Hizmetleri Kanunu-Madde 36:

İl müdürlüklerinin taşınır ve taşınmaz bütün mal ve paraları Devlet malı hükmündedir. İl müdürlüklerinin malları ile gelirleri ve alacakları haczedilemez.

3289 sayılı Gençlik ve Spor Hizmetleri Kanunu-Ek Madde 9: 
kaldırır mahiyette bir düzenlemedir. Dolayısıyla madde metni bir bütün olarak incelendiğinde, hükümdeki 'şikayet şartı aranmaksızın' ifadesinin yalnızca 5237 sayılı Yasanın 86. maddesinin 2. fikrasında ifadesini bulan basit tıbbi müdahale ile giderilebilecek kasten yaralama suçu bakımından hukuki bir anlam barındırdığını belirtmek yanlış olmayacaktır. Diğer taraftan spor alanlarında mala zarar verme suçunun işlenmesi halinde, Gençlik ve Spor İl Müdürlüğü’nün suçtan zarar gördüğü kabul edilmelidir. Nitekim uygulamada mala zarar verme suçu hakkında kurulan mahkumiyet hükümlerinin Gençlik Hizmetleri ve Spor İl Müdürlüğü'ne tebliğ edildiği görülmektedir. Aksi yönde uygulama ise Yargıtay tarafından bozma sebebi yapılmıştır ${ }^{62}$.

Son olarak burada Sermaye Piyasası Kanunu'na muhalefet suçları ile ilgili benzer bir düzenlemeye 6222 sayılı Kanunda da yer verilmesi gerektiğini belirtmekte yarar görüyoruz. Zira 6362 sayılı Sermaye Piyasas Kanunu'nun 115. maddesinin 1. fikrasında "Bu Kanunda tanımlanan veya atıfta bulunulan suçlardan dolayı soruşturma yapılması, Kurul tarafından Cumhuriyet başsavcılığına yazılı başvuruda bulunulmasına bağlıdır. $\mathrm{Bu}$

...Gençlik ve Spor Bakanlığı tarafından yapılan yardımlar ve tahsis edilen kaynaklar kullanılarak alınan taşınmazların mülkiyeti Gençlik ve Spor Bakanlığına ait olur. Bu taşınmazlar Gençlik ve Spor Bakanlığının mevzuatı çerçevesinde kullanılır. Federasyon malları Devlet malı hükmündedir, haczedilemez.

62 “...Sanık hakkında 21/04/2013 tarihinde Manisaspor-Denizlispor futbol takımları arasında yapılan spor müsabakası esnasında stadyumdaki seyirci koltuklarından birisini kırdığı iddiasıyla kamu davası açılmıştır. 6222 sayılı Kanun'un spor alanlarında taşkınl1k yapılması ve tesislere zarar verilmesi başlığ 1 altında düzenlenen 17. maddesinin birinci fikrasının ikinci cümlesinde 'spor alanları ve bu alanlardaki eşya, mala zarar verme suçu bakımından kamu malı hükmündedir.' düzenlemesine yer verilmiştir. 3289 sayılı Spor Genel Müdürlüğünün Teşkilat ve Görevleri Hakkında Kanun'un 36. maddesine göre, bir kamu kurumu olması dolayısıyla Spor Genel Müdürlügü’nün bütün taşınır ve taşınmaz malları, Devlet Malı hükmündedir. Yine anılan kanunun ek 9. maddesi uyarınca bağımsız federasyon malları Devlet Malı hükmündedir. Bu açıklamalar 1şığında somut olay değerlendirildiğinde; mahkemece gıyabi kararın suçtan zarar gören, davaya katılma ve kanıt sunma ile hükmü temyize hak ve yetkisi bulunan Gençlik Hizmetleri ve Spor İl Müdürlügü̉'ne tebliğ edilmediği, anlaşıldığından gerekçeli kararın anılan kuruma tebliğ işlemleri gerçekleştirildikten ve verilmesi halinde temyiz dilekçesi eklendikten ve ek tebliğnamede düzenlendikten sonra Dairemize gönderilmek üzere, incelenmeksizin mahalline iadesi için Yargıtay Cumhuriyet Başsavcılığına tevdiine... karar verildi." (Yargitay 19. Ceza Dairesi, 17/05/2016, 2015/33086 Esas, 2016/18158 Karar, www.kazanci.com) "...Mahkemece gerekçeli kararın suçtan zarar gören ve davaya katılma hakkı bulunan Gençlik Hizmetleri ve Spor İl Müdürlüğü'ne tebliğ edilmediği anlaşılmıştır." (Yargıtay 19. Ceza Dairesi, 02/03/2016, 2015/12517 Esas, 2016/3383 Karar, www.kazanci.com) 
başvuru muhakeme şartı niteliğindedir." şeklinde bir düzenlemeye yer verilmiş ve Sermaye Piyasası Kurulu'nun ihbarı atıf yapılan suçlarda muhakeme şartı olarak düzenlenmiştir. Biz de 6222 sayılı Kanun kapsamında yalnızca müsabaka alanında işlenen suçlardan dolayı ceza soruşturması başlatılabilmesi için ilgili spor federasyonunun ihbarının muhakeme şartı olarak düzenlenmesi ve bu konuda kanunda evleviyetle düzenleme yapılması gerektiği kanaatindeyiz.

\section{SONUÇ}

Ulaşım ve teknoloji başta olmak üzere diğer alanlardaki gelişme ve bütünleşmelerle birlikte kapsamı gün geçtikçe genişleyen spor ve bilhassa seyir yönü yüksek olan futbol adeta bir meslek halini almış ve ekonomik bir faaliyet olarak kabul edilmeye başlanmıştır. Başta futbol sahaları olmak üzere spor alanlarında yaşanan şiddet ve düzensizlik vakıaları da bu gelişimin bir handikapı olarak ortaya çıkmış ve bu durum spor mevzuatının etkin bir şekilde düzenlenmesi gerekliliğini gözler önüne sermiştir. Her ne kadar doktrinde bazı yazarlar ve Yargitay tarafından spor hukukunun ayrı ve bağımsız bir hukuk dalı olarak kabul edilemeyeceği belirtilmişse de başta 6222 sayılı Kanun olmak üzere gerek ulusal gerekse uluslararası nitelikteki normatif düzenlemeler spor hukukunun bağımsız ve karma nitelikli bir branş olarak değerlendirilmesi gerektiğini ortaya koymaya yetmektedir.

Başta futbol müsabakaları olmak üzere, tüm spor müsabakalarında son zamanlarda artan şiddet ve düzensizliklerin önüne geçilmesi için kanun koyucu tarafından öncelikle 5149 sayılı Spor Müsabakalarında Şiddet ve Düzensizliğin Önlenmesine Dair Kanun kaleme alınmış, akabinde işbu kanunun ihtiyaçlara cevap vermemesi sebebi ile 6222 sayılı Sporda Şiddet ve Düzensizliğin Önlenmesine Dair Kanun ihdas edilmiştir. İşbu kanunun 'yasak fiiller ve ceza hükümleri' başlıklı üçüncü bölümünde, 14. maddede 'hakaret içeren tezahürat', 17. maddede ise 'spor alanlarında taşkınlık yapılması ve tesislere zarar verilmesi' eylemleri ve bu eylemler karşılığında uygulanacak olan yaptırımlar hüküm altına alınmıştır.

6222 sayılı Kanun'un 'hakaret içeren tezahürat' başliklı 14. maddesi ile ilgili olarak belirtilmesi gereken ilk husus madde başlığının içeriği ile örtüşmediğidir. Zira madde metninin ilk fikrasında düzenlenen eylemin faili yalnızca taraftar olabilirken, maddenin 2. fikrası fail bakımından bir özellik arz etmez. Oysa madde metninin başlığının 'hakaret içeren tezahürat' olması maddenin 2. fikrasında hüküm altına alınan eylemin failinin de yalnızca taraftar olabileceği düşüncesini uyandırmaktadır ki bu durum kanun yapma tekniği bakımından kabul edilebilir mahiyette değildir. Kanaatimiz, ya 
madde içeriği ile bağdaşır mahiyette bir madde başlı̆̆ının tanzim edilmesi ya da maddenin fail bakımından özellik arz etmeyen 2. fikrasının madde dışına çıkarılması gerektiği yönündedir. Diğer taraftan 14. maddenin 1. fikrasındaki 'fiilleri daha ağır cezayı gerektiren başka bir suç oluşturmadığı takdirde' şeklindeki ibare kanaatimizce, hakaret içeren eylemin belirli bir kişiyi hedef almas1 durumunda 5237 say1lı Türk Ceza Kanunu'nun 125. maddesinin tatbik edilmesi gerektiğini ortaya koyar niteliktedir.

İfade ettiğimiz üzere 14. maddenin 1. fikrasında hüküm altına alınan eylemin faili yalnızca taraftar olabilir. İşbu düzenlemeye göre taraftarların hakaret içeren eylemleri şikâyet şartı aranmaksızın soruşturulacaktır. Oysa müsabaka alanlarındaki sporcuların, 6222 sayılı kanunun uygulama alanı olan yer ve zamanda, gerek diğer sporculara, gerek hakem ve diğer görevlilere, gerekse taraftarlara yönelik hakaret içeren ve kanunun 14. maddesinin 2. fikrası kapsamında değerlendirilemeyecek olan eylemleri 6222 sayılı Kanun'un kapsamına girmemektedir. Dolayısıyla böyle bir durumun varlığ1 halinde, genel hükümlere göre soruşturma başlatılacak ve 5237 sayılı Türk Ceza Kanunu'nun bilhassa 'hakaret' başlıklı 125. maddesi ve diğer ilgili maddeler somut olaya tatbik edilecektir. Buna göre mağdur kamu görevlisi ise şikâyet şartı aranmaksızın soruşturma başlatılacak; kamu görevlisi değilse mağdurun şikayeti üzerine soruşturma başlatılabilecektir. Diğer taraftan kanunun 14. maddesinin 2. fikrasında hüküm altına alınan eylemin fail bakımından bir özellik arz etmediği izahtan varestedir. Doktrinde işbu düzenleme ile ilgili olarak 5237 sayılı Yasanın 216. maddesinin 2. fikrasına atıf yapılmakta ve düzenlemelerin benzer olduğu vurgulanmaktadır. Kanaatimiz gerek madde metnindeki "fiili daha ağır cezayı gerektiren başka bir suç oluşturmadığı takdirde" ifadesi gerekse 5237 sayılı kanunun "fikri içtima' başlıklı 44. madde düzenlemesi karşısında 216. maddenin 2. fikrası kapsamında kalan bir eylemin varlığı halinde işbu hükmün tatbik edilmesi gerektiği yönündedir.

Sporcuların, diğer sporculara, hakeme veya taraftara yönelik kasten yaralama suçunu oluşturan eylemleri ya da mala zarar verme suçunu oluşturan eylemleri 6222 sayılı Kanun'un 17. maddesinin delaletiyle şikâyet şartı aranmaksızın Türk Ceza Kanunu'nun ilgili hükümlerine göre değerlendirilecektir. Fakat sporcuların kasten yaralama suçunu oluşturan eylemlerinin 6222 sayılı Kanun kapsamında değerlendirilebilmesi için müsabaka esnasındaki pozisyon gereği yapılan müdahaleler kapsamında olmaması, yani yaralama kastı ile gerçekleştirilmiş olması gerekir.

6222 sayıl1 Kanunun 17. maddesinde gerek kasten yaralama gerekse mala zarar verme suçunun spor alanlarında işlenmesi hali düzenlenmiştir. 
Kanaatimiz, spor alanına ilişkin kanunun 3. maddesindeki tanım gözetildiğinde yasanın 17. maddesindeki düzenlemenin uygulama alanı bakımından kanunun amacina hizmet etmediği yönündedir. Zira hiç şüphesiz ülkemizdeki sporda şiddet ve düzensizlik eylemleri yoğun olarak spor alanlarının dışında gerçekleşmektedir. Dolayısıyla kanun koyucu tarafından bu durum dikkate alınarak, madde metnindeki spor alanları ifadesinin hükümden çıkarılması ve bilhassa müsabakanın yapılacağı yere gidiş ve geliş güzergahları ile taraftarların sürekli veya geçici olarak gruplar halinde bulundukları yerleri kapsayacak şekilde bir düzenleme yapılması gerekir. Zira kanundaki bu eksiklik, 6222 sayılı Kanun'un işlevini yerine getirememesine sebep olmakta ve çoğunlukla müsabaka alanına gidiş ve geliş güzergahlarında gerçekleşen basit tıbbi müdahale ile giderilebilecek kasten yaralama ve mala zarar verme suçlarının şikayet şartı gerçekleşmediği için soruşturulmamasına yol açmaktadır.

Diğer taraftan her ne kadar 6222 sayılı Kanun'un 17. maddesinde her iki suç bakımından da şikâyet şartı aranmaksızın soruşturma yapılacağı şeklinde bir düzenleme yapılmışsa da, aslında "spor alanları ve bu alanlardaki eşya, mala zarar verme suçu bakımından kamu malı hükmündedir." düzenlemesi, mala zarar verme suçu bakımından şikâyet şartını ortadan kaldırır mahiyette bir düzenlemedir. Hal böyleyken hükümdeki 'şikâyet şartı aranmaksızın' ifadesinin yalnızca 5237 sayılı Yasanın 86. maddesinin 2. fikrasinda ifadesini bulan basit tıbbi müdahale ile giderilebilecek kasten yaralama suçu bakımından hukuki bir anlam barındırdığını belirtmek yanlış olmayacaktır. Yine ifade etmek gerekir ki spor alanlarında mala zarar verme suçunun işlenmesi halinde, Gençlik ve Spor İl Müdürlüğü'nün suçtan zarar gördüğ̈ kabul edilmekte ve mahkûmiyet hükümleri kuruma tebliğ edilmektedir. Aksi yönde uygulama ise Yargıtay tarafından bozma sebebi yapılmıştır.

Son olarak Sermaye Piyasas1 Kanunu'nun 115. maddesinin 1. fikrasindaki düzenlemeye benzer bir biçimde, 6222 sayılı Kanun kapsamında yalnızca müsabaka alanında işlenen suçlardan dolayı ceza soruşturması başlatılabilmesi için ilgili spor federasyonunun ihbarının muhakeme şartı olarak düzenlenmesi ve bu konuda kanunda evleviyetle düzenleme yapilmas1 gerektiğini belirtmekte yarar görüyoruz. 


\section{KAYNAKÇA}

Artuk, Mehmet Emin/Gökcen, Ahmet/Yenidünya, Caner: Türk Ceza Kanunu Şerhi, 3. Cilt. Adalet Yayınevi, 2. Bask1, Ankara 2014.

Baştürk, Faruk: İş Hukukunda Profesyonel Futbolcu, Beta Basım Yayın, 1. Bask1, İstanbul 2007.

Bilir, Pervin/Avgın, Anıl: "“Ceza Alan Futbol Taraftarlarının Şiddete Yönelik Davranışlarının İncelenmesi: Adana İli Örneği”"» Spor ve Performans Araştırmaları Dergisi, s. 232-251.

Erkiner, Kısmet: "“Türkiye'de Spor Hukukunun Oluşumu”» İstanbul Barosu Dergisi Spor Hukuku Özel Sayısı, 2007.

Ertaş, Şeref/Petek, Hasan: Spor Hukuku, Yetkin Yayınevi, 3. Baskı, Ankara 2017.

Erten, Rifat: Milletlerarası Özel Hukukta Spor, Adalet Yayınevi, 1. Bask1, Ankara 2007.

Fişek, Kurthan: Devlet Politikası ve Toplumsal Yapıyla İlişkileri Açısından Dünya'da ve Türkiye'de Spor Yönetimi, A.Ü SBF Yayınları, 2. Bası, Ankara 1998.

Genç, Durmuş Ali: Futbol Kulüplerinin Stratejik Yönetimi, Bağırgan Yayınevi, Ankara 1999.

Gerçeker, Hasan: Spor Hukuku, Seçkin Yayıncılık, 1. Bask1, Ankara 2016.

Göktürk, Neslihan: Fikri İçtima, Adalet Yayınevi, 1. Bask1, Ankara 2013.

Gülşen, Recep: Spor Hukuku, Adalet Yayınevi, 2. Baskı, Ankara 2013.

Günal, A. Nadi/Küçükgüngör, Erkan: «"Türk Spor Teşkilatının Hukuki Yapısı"» Türkiye Barolar Birliği Dergisi, 1998/3, s. 1035-1065.

Güneş, İsmail: Futbol Ekonomisi, Karahan Kitabevi, 1. Bask1, Adana 2010.

Hyperlink "http://www.tdk.gov.tr" http://www.tdk.gov.tr, Erişim Tarihi: 21 Aralık 2019.

Hürmüz, Peyman: 6222 Sayılı Sporda Şiddet ve Düzensizliğin Önlenmesine Dair Kanun Yasak Filler ve Ceza Hükümleri, Adalet Yayınevi, 1. Bask1, Ankara 2016.

Karakaş Doğan, Fatma: " "Futbol Taraftarlarının Hakaret İçeren Tezahürat Eylemlerinin Ceza Hukuku Açısından Değerlendirilmesi"»» Ceza Hukuku Dergisi, 2015: 83-106. 
Kıraç, Erkan: "“Futbolda Şiddet ve Çıkış Yolları Üzerine Bir Deneme”» http://www.sporhukuku.org/futbolda-siddet-ve-cikis-yollar1-uzerinebir-deneme/ Erişim Tarihi: 27 Aralık 2018.

Koca, Mahmut: 6222 Sayılı Sporda Şiddet ve Düzensizliğin Önlenmesine Dair Kanunda Düzenlenen Suçlar ve Kabahatler, Seçkin Yayıncılık, Ankara 2012.

Koca, Mahmut/Üzülmez, İlhan: Türk Ceza Hukuku Özel Hükümler, Adalet Yayınevi, Beşinci Bask1, Ankara 2018.

Kocalar, Salih/Biçen, Yunus: Kasten Yaralama Suçu Örneğinde Genel Hükümler, Seçkin Yayıncılık, 1. Baskı, Ankara 2019.

Kocaoğlu, Serhat Sinan: Uluslararası (AİHM) ve Ulusal Yargı İçtihatları Çerçevesinde Hakaret Suçu, Seçkin Yayıncılık, 1. Baskı, Ankara 2019.

Kocasakal, Ümit: "“Spor Hukukunun Özellikleri Çerçevesinde Tahkim Yargllaması ve Türkiye Futbol Federasyonu Tahkim Kurulu”» İstanbul Barosu Dergisi, 2007.

Koçak, Talat Emre: Türkiye Futbol Federasyonu Tahkim Kurulu, Seçkin Yayınc1lık, 1. Bask1, Ankara 2007.

Kuru, Emin: «Türkiye’de Spor Seyircilerinde Oluşan Kitlesel Tezahüratın Geleneklerle İlişkisi» Milli Folklor. 2009.

Özbek, Veli Özer/Doğan, Koray/Bacaksız, Pınar/Tepe, İlker: Türk Ceza Hukuku Genel Hükümler, Seçkin Yayıncılık, 9. Baskı, Ankara 2018.

Özelçi, Aytaç: Türkiye Futbol Federasyonu'nun Türk Hukukundaki Yeri, Seçkin Yayıncılık, 1. Baskı, Ankara 2010.

Petek, Hasan: Profesyonel Futbolcu Sözleşmesi, Yetkin Yayınevi,1. Baskı, Ankara 2002.

Sarıibrahimoğlu, Y. Selim/Bakanay, Mehmet Ali/Tekin, Tarık: Spor Hukuku. Ankara 2002.

Şen, Ersan: "“6222 Sayll Kanun ve Sporda Ceza Sorumluluğu”» http://www.haber7.com/yazarlar/prof-dr-ersan-sen/1692923-6222sayili-kanun-ve-sporda-ceza-sorumluluğu. Erişim Tarihi: 4 Ocak 2019.

Tabel, Taner: «"6222 Sayılı Kanunun Uygulama Sorunları ve Çözüm Yollar1 Paneli”» http://olimpiyatkomitesi.org.tr/editorimages/seminer/ sporhukuku2014, Erişim Tarihi: 2 Ocak 2019.

Taneri, Gökhan/Kamışlı, Gani: Kişilere Karşı İşlenen Suçlar, Seçkin Yayıncılık, Birinci Baskı, Ankara 2018. 
Türkmen, Mustafa/Yıldız, Kadir/Zekioğlu Aylin: "“Sosyolojik Açıdan Şiddet ve Çirkin Tezahüratın Nedenlerinin Araştırllması: Manisaspor Taraftarları Örneği”" Spor Yönetimi ve Bilgi Teknolojileri Dergisi, 2013: 17-18.

Uslu, Ferhat: Spor Hukuku Dersleri, Adalet Yayınevi, 1. Baskı, Ankara 2016.

Uzun, Aziz/Eker, Semih/Pakiş, Iş11/Polat, Oğuz: "Üniversite Öğrencileri Arasında Sporda Şiddetin Önlenmesine Yönelik Farkındalık ve Bilgi Düzeyi Araştırması", Türkiye Biyoetik Derneği Yayınları, İstanbul 2012.

Yurtcan, Erdener: Sporda Şiddet ve Düzensizliğin Önlenmesi Kanunu ve Yorumu, Kare Yayınları, 1. Baskı, İstanbul 2006.

Yurtcan, Erdener: Sporda Şiddetin ve Düzensizliğin Önlenmesi Kanunu ve Yorumu-6222 sayılı Yasaya Göre Yeniden Yazılmış, Adalet Yayınevi, 2. Bask1, Ankara 2011.

Zafer, Hamide: Ceza Hukuku Genel Hükümler, Beta Yayınları, 6. Bask1, İstanbul 2016. 